\title{
INCLUSIVE BOUNDARIES AND OTHER (IM)POSSIBLE PATHS TOWARD COMMUNITY DEVELOPMENT IN A GLOBAL WORLD
}

\author{
FRAN ANSLEY ${ }^{\dagger}$ \\ INTRODUCTION
}

When the organizers of this Symposium on "Social Movements and Law Reform" invited me to participate with the understanding that I would talk about community economic development (CED), it seemed a bit ironic to me. My work is less about the issues and concerns that occupy the attention of most CED lawyers (crucial things like affordable housing finance and small business planning), and more about what I have come to think of as the world of community un-development. I began studying and writing over a decade ago about the phenomenon of plant closings and the harsh impact of deindustrialization on individuals and communities in my own state and across the United States.' The lessons I have been contemplating

${ }^{\dagger}$ Professor of Law, University of Tennessee College of Law; B.A. Harvard/Radcliffe 1969, J.D. University of Tennessee 1979, LL.M. Harvard Law School 1988. I cannot thank all the people who have helped me develop the ideas and understandings that inform this paper. On the other hand, I cannot omit to thank a few. First, of course, Ed Rubin, Susan Feathers, and the others at the University of Pennsylvania who have been such gracious intellectual and material hosts, the speakers and writers who shared their work at this Symposium, and the student editors at the Law Review whose patience and diligence have been so sterling. Individuals and organizations active around issues of plant closings and immigrants' rights have taught me what no one else could have. Among them are Jennifer Gordon, Anne Lewis, Staughton and Alice Lynd, Sergio Rodriguez, Jeannine Ugarte, Mike Whalen, plus friends at the Coalition of Immokalee Workers, Good Jobs First, Highlander Research \& Education Center, Latino Memphis Conexión, Tennessee Industrial Renewal Network, and many of my students at the law school who have worked on projects related to immigrants in Tennessee and elsewhere. In the past two years, my greatest teachers on social movement practice have been students and workers on my own campus who stepped forward to create United Campus Workers and the Progressive Student Alliance. Several organizations have provided me with financial support for different projects that continue to bear fruit here, including the Angelina Fund, Appalshop, Inc., the Carnegie Foundation for the Advancement of Teaching, the Fund for Labor Relations Studies, the Social Sciences and Humanities Research Council of Canada, the U.S. Department of Housing and Urban Development, and the University of Tennessee and its College of Law.

\footnotetext{
See, e.g., Fran Ansley, Standing Rusty and Rolling Empty: Law, Poverty, and America's
} 
from these investigations are more about unraveling and upheaval than they are about enterprise development, more about the chopping block than the incubator.

On the other hand, on the "Social Movement" side of the title of this Symposium, I can see why conveners might have thought I would have something to offer. An important part of my initial project on deindustrialization was spent as a participant-observer in what was known at the time as the "plant-closing movement." I worked closely with an organization in Knoxville that was a local manifestation of this current, ${ }^{3}$ and I interviewed workers, lawyers, and activists who were part of regional and national networks committed to finding effective responses at each of those levels to the unprecedented reorganization of industrial production that made itself so evident from the late 1970 s into the $1990 \mathrm{~s}^{4}$

Eroding Industrial Base, 81 GEO. L.J. 1757 (1993) (relating recent plant closings and the legal avenues explored by those adversely affected, and discussing the direction the law could and should take regarding issues raised by plant closings). The word "deindustrialization" deserves comment. The book that popularized and may have invented the term is Barry Bluistone \& BenNetT Harrison, The Deindustrialization of AMERICA (1982). Others have argued that "re-industrialization" might be the more apt expression since industry has surely not disappeared from the United States entirely, but has been reorganized, relocated, and restructured. At any rate, there is an unmistakable shift in the U.S. labor force from the industrial to the service sector, fueled in part by automation, in part by growth in new service occupations, and in part by the relocation of industrial facilities to countries overseas. From a sectorial perspective, some industries-such as garments, coal, or consumer electronics-have been particularly hard-hit by one or more of these dynamics. And of course from a local perspective, some specific communities have been stripped of $100 \%$ of their manufacturing base when plants closed.

${ }^{2}$ For some entry points into the plant-closing movement in its heyday, see COMmUNITY AND CAPITAL IN CONFLICT (John C. Raines et al. eds., 1982); STAugHTON LYND, THE FIGHT AGAINST SHUTDOWNS: YOUNGSTOWN'S STEEL MILL ClOSINGS (1982); ERIC MANN, TAKING ON GENERAL MOTORS: A CASE STUdY OF THE CAMPaign to KeEP GM VAN NUYS OPEN (1987); Lawrence G. Flood, Union-Community Relations in Buffalo: A Preliminary Assessment, 39 BUFF. L. REv. 445 (1991); Bruce Nissen \& Lynn Feekin, For the Public Good: Calumet Project Organizes for Labor and Community-Based Economic Development, LAB. RES. REV., Spring 1992, at 15. For a widely-viewed documentary about plant closings that served in some ways as the movement's definitive cinematic statement, see Michael Moore's RoGER AND ME (Dog Eat Dog Films 1990). For a defense of corporate practice and a critique of key assumptions and demands of the plantclosing movement, see RICHARD B. MCKENZIE, Fugitive INDUSTRY: THE ECONOMICS and Polttics of Deindustrialization (1984); and Plant Closings: Public or PRIVATE CHOICES? (Richard B. McKenzie ed., 1984).

"The group-still very much in existence, and still doing important work, though now involved in a broader range of economic justice issues than simply plant closingsis the Tennessee Industrial Renewal Network (TIRN). Information on this group is available at its website <www.tirn.org $>$.

${ }^{4}$ This Article represents the first time in print that I have referred to the plant- 
Accordingly, one line of discussion that I could have pursued in my talk and in this Article would have been to describe the plantclosing movement as I knew and learned about it in the 1980s and 1990 s from my location in the southeastern United States, and to relate that description to some piece of the burgeoning literature on social movements that our conveners have so fruitfully invited us to consider. Indeed, that kind of examination would be well worth someone's time.

Such an examination could draw on a fascinating body of work by social scientists: case studies and theories on social movements that constitute a resource for academics and activists alike, and that should be of particular interest to people who want to understand law and the dynamics of law reform. ${ }^{5}$ The definition of "social movement" is hardly settled, but Sidney Tarrow's formulation serves well enough to represent the field. He has said that social movements are "collective challenges by people with common purposes and solidarity in sustained interactions with elites, opponents, and authorities."

closing movement as something properly situated in the past tense. Others may disagree with my decision to do so. Certainly corporations are still closing and moving industrial production, and certainly communities and workers still seek ways to resist or protest those decisions. See, e.g., UNITED STUDENTS AGAINST SWEATSHOPS, MONEY MADE, WORKERS FORGOTTEN: THE UNTOLd STORIES OF THE GLOBAL RACE TO THE BOTTOM IN WESTERN NEW YORK (2001), available at http://www.usasnet.org/ campaigns/newera/report.shtml (describing the plight of factory workers in Western New York); Rick Bragg, Brown Longs, Lost Fingers; Now, a Lost Mill, N.Y. TiMES, May 16, 2001, at A1 (documenting the closing of the Union Yarn Mill in Jacksonville, Alabama). However, the surrounding context has changed in important ways, including the fact that domestic unemployment rates have significantly eased since the time when the plant closing movement was at its height. In addition, fewer workers today have the kind of baseline expectations about job security that provided the emotional fuel for many earlier plant closing fights.

Although I have concluded that the past tense is in order here, I do not think the plant-closing movement came to an end so much as it evolved into something potentially much broader and deeper. Contemporary efforts that have been inspired, fed and joined by currents from the old plant-closing movement include the diverse coalitions now protesting neoliberal free-trade agreements, the nationwide bloom of local living wage campaigns, and the network of local or state-wide projects attacking corporate subsidy abuse and demanding that governments adopt policies that promote "good jobs."

"For a particularly helpful bibliography, see ROBERTA GARNER \& JOHN TENUTO, SOCIAL MOVEMENT THEORY AND RESEARCH: AN ANNOTATED BIBLIOGRAPHICAL GUIDE (1997).

${ }^{\circ}$ Sidney Tarrow, Power in Movement: Social Movements, Collective ACTION AND POLITICS 3-4 (1994) (emphasis omitted). Tarrow is one of a number of theorists who decisively moved away from older schools that viewed social movements more as sites of deviant behavior than potential motors for positive change. For one example of the older approach, see NEIL J. SMELSER, THEORY OF Collective 
definition obviously pitches a big tent. Despite great differences among the groups and activities encompassed in the theory's objects of study, scholars have struggled to develop categories that can be fruitfully applied across a wide range of groups. ${ }^{7}$

Social movement scholars have asked questions about why and when movements arise and spread (or not), how long they last, what sorts of action their members undertake, under what conditions they "succeed," and so on. Using quantitative and qualitative tools, these scholars have searched for factors that could predict or explain the wellsprings, characteristics, growth, impact, and decline of social movements. Some of the concepts they have identified would serve as a fascinating retrospective lens for assessing the strengths and weaknesses, messages, and meanings of the plant-closing movement and its trajectory.

For instance, one of the categories that has emerged in social movement theory is that of "political opportunity structure," a term that refers to elements in the relevant political environment that work to enable, condition or retard a given social movement. Political opportunity structures include, for instance, the fracture or unity of ruling elites, the stability or fluidity of existing political alliances and coalitions, the presence or absence of allies or countermovements, whether would-be reformers have access to insider channels or must resort to outsider strategies, ${ }^{8}$ the repression or tolerance shown by the

\footnotetext{
BEHAVIOR (1962).

${ }^{7}$ It sometimes seems nevertheless that the definitions and categories of social movement theory are so broad as to limit their utility. Some have asked, for instance, whether social movernent theory should try to develop analytical tools that would allow it to differentiate between social movements on the basis of which systems of privilege and power they target or which kinds of social change they envision. On a more quantitative axis, others have suggested that it might be important to develop criteria of size and scope. That is, perhaps social movement theory should develop coherent ways to differentiate a social movement, from, say, a campaign or an organization. It may be more confounding than helpful to conceptualize large, sustained, deeply-rooted movements in the same terms as smaller, briefer, more localized, or otherwise limited campaigns. In the immediate context of this Article, for instance, the plant-closing movement did not come close to the breadth of appeal, depth of participation, or duration in time of the (arguably paradigmatic) American civil rights movement of the $1960 \mathrm{~s}$. It may be that the two are best understood as representing two qualitatively different phenomena. Certainly the challenges and opportunities facing organizers in a time of broad-scale mobilization and grassroots activity are different from those facing them in a time of widespread quiescence. Despite these questions about the categories, I will continue to refer to the "plant-closing movement" in the text above and will assume that the phrase is serviceable enough for present purposes.

${ }^{8}$ Note that a relatively closed system may be more conducive to the development of social movements than one that provides more opportunities for individual expres-
} 
state toward protest activity, and the existence of structural inequalities that have been created, exacerbated. or highlighted in some way that has brought them newly and vividly into public consciousness."

A second category that some theorists have offered to explain social movement origins and their trajectories is that of "mobilizing structures." This concept includes the formal and informal organizational resources that movements are able to create or call upon in their efforts to develop effective strategies and tactics. Such resources may include the movement's own individual and organizational members, its public allies or private friends, other movements that are open to collaborations and alliances, effective movement leaders and organizational professionals, access to media outlets, control of material resources, and the existence and range of familiar forms of collective action, or "repertoires," that are known by those in the relevant setting to have proved successful in the past."

A third, and slightly younger, concept from social movement theory that might cast helpful light on the plant-closing movement is that of the "framing process." This category of analysis reflects scholars' growing recognition that ideas, meanings, and felt identities matter greatly in the development of social movements. Relying in part on cognitive and linguistic research into the ways that human beings make sense of experience, researchers have pointed out that "meaning work" is central to both the subjective experiences and objective impacts associated with social movements. Often one of the most critical indicators of a social movement's capacity to grow and wield influence is whether its way of conceptualizing the issue is taken up by relevant constituencies. Although the capacity to prevail in this way will surely depend, in part, on the political opportunities available to a given social movement, and, in part, on the resources the movement can muster and deploy, it will also depend on the memories, beliefs, emotions and identifications of the movement's members and those

sion and mobility, especially if the social movements can find powerful allies beyond the immediately repressive regime. For a recent description of the disturbing and paradoxical ways that South Africa's social-movement trade unionism has declined and become disoriented since the fall of apartheid, see Sakhela Buhlungu, The Paradox of Victory: South Africa's Union Movement in Crisis, NEw LAB. F., Spring-Summer 2001, at 6776.

? For an illustrative study that focuses largely on the role of political opportunity structures, see Sidney TARROW, DEMOCRACY AND DISORDER: PROTEST AND POLITICS IN ITALY, 1965-1975 (1989).

${ }^{10}$ For a collection of papers related to resource mobilization, see SocIAL MOVEMENTS IN AN ORGANIZATIONAL SOCIETY (Mayer N. Zald \& John D. McCarthy eds., 1987). 
of its potential adherents and opponents."

Arguably all actors interested in gaining or maintaining political power-from outsider democratic challengers to well-defended authoritarian rulers-can enhance their power if they are able to articulate an ideological frame that makes sense of their actions, justifies their policies, and legitimizes their claims to authority. In the case of social movements, however, success at framing the issues is particularly crucial because they must be able to move people voluntarily into sometimes risky action, and, ordinarily, they must recruit these volunteers without recourse to the structures, incentives, and general momentum available to those with access to existing political channels. Social movements thus have no alternative but to develop compelling frames that attract and energize members. Further, as will be explored below, social movements must use frames that emphasize the rightness and efficacy of collective action.

Debates continue over the relative force of these sometimes more material and sometimes more psychological approaches to social movement analysis, but many commentators today acknowledge that all three of the categories-political opportunities, mobilizing structures, and framing processes-make some difference and are at work in most situations, often interdependently. ${ }^{12}$ As our hosts have suggested by convening this Symposium, lawyers and legal scholars have a lot to gain from a greater familiarity with the body of work in the social sciences through which these and other analytical tools have been forged, because it constitutes an important potential resource for better understanding the relationship between law and social change. ${ }^{13}$ Certainly, an examination of the plant-closing movement-the politi-

\footnotetext{
11 For more on framing processes, see David A. Snow \& Robert D. Benford, Master Frames and Cycles of Protest, in FrontIERS IN SOCIAL MOVEMENT THEORY 133 (Aldon D. Morris \& Carol McClurg Mueller eds., 1992); and Sidney Tarrow, Mentalities, Political Cultures, and Collective Action Frames: Constructing Meanings Through Action, in FroNTIERS IN SOCIAL MOVEMENT THEORY, supra, at 174. For a case study that is both sympathetic and critical, see Lorraine Bayard de Volo, Global and Local Framing of Matermal Identity: Obligation and the Mothers of Matagalpa, Nicaragua, in GLOBALIZATIONS AND SOCIAL MOVEMENTS 127 (John A. Guidry et al. eds., 2000) .

${ }^{12}$ For two collections that tend toward integrated perspectives on these social movement categories, see Comparative Perspectives on Social Movements: Political Opportunities, Mobilizing Structures, and Cultural Framings (Doug McAdam et al. eds., 1996); and FrontiERs IN SOCIAL MOVEMENT THEORY, supra note 11.

${ }^{13}$ For a study that pays close attention to the dynamic interaction between social movement activity and law-making, see MICHAEL. W. MCGANN, RIGHTS AT WORK: PAY EQUI'TY REFORM AND THE POLITICS OF LEGAL MOBILIZATION (1994).
} 
cal opportunities that were available to it, the resources it mobilized, and the way it framed its issues-should enable better understanding of the movement, and should provide a fuller account of the law related to plant closings than would a study confined to the examination of isolated legal doctrine. ${ }^{14}$

However, my ambitions here will be more modest. Although I will sketch some basic outlines of the plant-closing movement and its general activities, that profile will neither provide a balanced history or thorough analysis of the movement as a whole, nor will it attempt to assess the movement's trajectory in light of all three of the thematic categories described above. Instead, I will focus on one aspect of my experience as an active participant in the movement's attempts to reframe the plant-closing issue, and I will share and try to unpack one particularly troubling dilemma I encountered in the course of my work in that framing process.

I should also say that, after the instant paragraph, this Article will treat as unremarkable the fact that I was involved in the plant-closing movement as an open partisan. In other words, I am not interestedat least in this venue-in undertaking a defense of politically engaged scholarship in general, or of my commitments to the plant-closing movement in particular. My intent is to offer stories and analysis that will be of interest to a broad group of readers, including some who identify with or participate in social movements, and some who choose to keep a greater distance. I assume that at least some of my readers are specifically asking questions about whether and how they might help create or support social movements capable of demanding more just and sustainable arrangements for the world's economy. I believe such goals are worthy subjects of scholarly inquiry and communication, and I will occasionally address them here. But I will also assume that observation by a social movement participant can provide material of genuine interest to readers who are not themselves engaged in-or who may be specifically opposed to-the particular

14 In the proper hands, a case study of the plant-closing movement might also help to further the process of refining and elaborating social movement theory. For a piece of participant observation that uses social movement theory to help make sense of a particular effort at local legal change, see Bruce Nissen, Living Wage Campaigns from a "Social Movement" Perspective: The Minmi Case, LAB. STUD. J., Fall 2000, at 29. This Article also sets an exemplary standard for engaged scholars about going public with honest and accessible reflection on their experiences in the field. For larger studies that more explicitly attempt to build theory through examination of case studies, see William A. Gamson, The Strategy of Social Protest (1975); and Tarrow, supra note 6. 
movement in question..$^{15}$

Proceeding on the foregoing assumptions, then, this Article will read something like a report from the field, a report in which I offer my own actions-and my own feelings of discomfort and bafflementas a kind of evidence about some more general aspects of social movements and law reform in today's globalizing age. ${ }^{16}$ A thesis of the piece, or, at any rate, a possibility I will ask you to entertain, is that this field report is worth your attention because it signals trouble, but also potential opportunity, for the larger and still highly uncertain project of "globalization from below."

15. I realize this is not an uncontroversial decision, and I do not mean to suggest that problems of bias and objectivity are easy ones. In another context, after acknowledging that some legal scholars would be troubled by "my open announcement of a chosen stance in the text," I offered the following standard, which I will take as my guide in this case as well:

My own belief is ... that an "unperspectived" view is impossible. In fact, I have come to believe that it is precisely the points of view we perceive as "nelltral " or "bias-free" that often contain the most powerful unexamined assumptions and blindnesses of all. ...

For present purposes let me say only that I believe it is important for scholars in particular and people in general to discover and acknowledge their own perspectives, and to recognize and listen to those different from their own. This article will endeavor to cite and reason widely enough that readers are alerted to a range of viewpoints and given sufficient information to pursue further inquiries.

Ansley, supra note 1, at 1762 n.14.

16. Thanks go to Mariolina Salvatori, one of my colleagues in the Carnegie Academy for the Scholarship of Teaching and Learning, for her idea about the importance of "difficulty" as a signal of emergent knowledge, and her infectious conviction that "difficulty papers" (writings that notice, value, and attempt to unpack moments of difficulty) can be privileged sites for the construction of knowledge. This Article is an attempt to emulate her method.

${ }^{17}$ Whether transnational social movements embodying something like "globalization from below" will in fact emerge and flourish on this earth is a large question, one which many scholars are attempting to study. Some are reporting on close observations of concrete practices that might represent, prefigure, or cast light on transnational social movements. See, for example, Mark Anner, Labor and Economic Globalization in Eastern Europe and Latin America, IAAB. STUD. J., Spring 2001, at 22, 32-37 (Spring 2001 ), which shows that the expansion of segmented production regimes have greatly weakened labor's power at the point of production; and Douglas Meyer, Building Union Power in the Global Economy: A Case Study of the Coordinated Bargaining Committee of General Electric Unions, LAB. STUD. J., Spring 2001, at 60, 71-74, which examines one instance of transnational labor collaboration within the context of a single transnational corporation. For various studies discussing international feminism, farmers in the EU, and protesters against the Gulf War and toxic waste practices, see Myra Marx Ferree \& William A. Gamson, The Gendering of Abortion Discourse: Assessing Global Feminist Infuence in the United States and Germany, in SOCIAL MOVEMENTS IN A GLObALIzING WORLD 40 (Donatella della Porta et al. eds., 1999) [hereinafter GLOBALIZING WORLD]; Bert Klandermans et al., Injustice and Adversarial Frames in a Supranational Poltical Context: Farmers' 


\section{WORKING IN THE FRAME SHOP}

The majority of my time with the plant-closing movement was spent in the framing enterprise, doing what I will call in this Article "framingwork" and serving as what I will call a "frameworker." Social movement theory tells us that in order to communicate effectively, movements-like other social and individual actors who undertake to speak and be heard in public fora-must find or construct frames that provide a way for listeners to understand them, cognitive scaffolds that work to organize perception and explain reality. Unlike just any old social actor looking for an audience, however, social movements must use a frame that valorizes and motivates collective action. William Gamson developed a widely cited formulation for what such a "collective action frame" requires. He said it must include three elements: (1) injustice (the frame presents the situation as unfair or unequal); (2) identity (the frame identifies an "us" and a "them," with the former seen to be suffering as a result of a situation for which the latter are responsible); and (3) agency (the frame offers the view that through

Protests in the Netherlands and Spain, in GLOBALIZING WORLD, supra, at 134; Ruud Koopmans, A Comparison of Protests Against the Gulf War in Germany, France and the Netherlands, in GLOBALIZING WORLD, supra, at 57; and Jackie Smith, Global Politics and Transnational Social Movements Strategies: The Transnational Campaign Against International Trade in Toxic Wastes, in GLOBALIZING. WORLD, supra, at 170.

Others are undertaking more synthetic work. See, e.g., STEVEN M. BUECHLER, Social Movements in advanced Capitalism: The Political EConomy and CUltural CONSTRUCiTION OF SOCIAL ACTIVISM (2000) (taking a historical approach to the understanding of collective action, and relating this knowledge to the broader discipline of sociology); John A. Guidry et al., Clobalizations and Social Movements, in GLOBALIZATIONS AND SOCIAL MOVEMENTS, supra note 11, at 1, 1-34 (examining a set of studies from various disciplines in an effort to understand the intersection between globalization and social movement). For a book that treats social movements in the course of a full-scale attempt at re-imagining modernity, capitalism, and the future of the human race, see BOAVENTURA de SOUSA SANTOS, TOWARD A NEW COMMON SENSE: l.aW, SCienci and Politics in the PARAdigmatic Transition (1995). Together with Cesar Rodriguez, Santos has served as co-convener of an international collaborative research network initiated under the umbrella of the Law \& Society Association and made up of scholars who are interested in studying, and perhaps animating, "counterhegemonic globalization." In the interest of full disclosure, I should note that I am a participant in this network. Meanwhile, doubters of the thesis (or dream) of "globalization from below" have not been shy about challenging the romance of such a project. See Yves Dezalay, Remarks on "Dollarization of Professional Expertises," at the annual meeting of the Law and Society Association, Miami Beach, Florida (May 2000); see also Enrique Carrasco, Opposition, Justice, Stnucturalism, and Particularity: Intersections Between LalCrit Theory and Law and Development Studies, 28 INTER-AM. L. REv. 313, 334 (1996-97) (asking whether LatCrit theory can help law and development scholars to articulate a more equitable alternative to neoliberal development models, in part through the use of "counter-hegemonic development stories 'from the bottom."). 
collective action "we" have the capacity to change the situation). ${ }^{18}$

The plant-closing movement tried to construct and project precisely such a frame. First, it cast its core issue-plant closings-as an instance of social injustice rather than some inexorable law of economic development. Second, the movement specified relevant identities, naming an "us" and a "them," and generally putting the blame for the core injustice not on workers or local communities, but on corporate decision makers and government officials. Finally, the movement worked to convince its constituents that their own power and agency was not a pipe dream, that if they worked together in local plantclosing organizations and coalitions, or in the larger national network, they could change the situation in a meaningful way-both through more and better bargains that could be hammered out in contentious negotiations among corporations, workers, and communities, and through enforcement victories and substantive reforms that could be won in legal arenas.

I was attracted to the idea of being a frameworker in the plantclosing movement because I believed then, as I do now, that cognitive frames and shared understandings have the power to expand or contract possibilities for justice. I saw this project as one in which there actually might be a chance to shift the nature of public debate on foundational questions of economic policy. Maybe, I thought, vigorous public arguments over the rights and wrongs of plant closings could help equip a bottom-up ideological challenge that could emanate from a wide range of workplace and community organizations and could offer a counterweight to the trickle-down economic gospel being pushed so aggressively by the Reagan administration at that time.

After all, broad segments of ordinarily quiescent Americans were irate about what corporations were doing. There was a strong feeling among many people that foundational promises were being broken, long-secure arrangements were crumbling, and profound questions about the past and future were in order. In communities all over the country, new coalitions of labor, religious, and community organizations were emerging with a focus and unity on matters of economic justice that had not been seen for decades. Fundamental questions about the nature and meaning of economic arrangements-and about the values that should guide them-were being debated on the evening news. In other words, at the time, it seemed that work on this

\footnotetext{
${ }^{18}$ William A. Gamson, Talking Politics 6-8 (1992).
} 
nographers, inviting them to solicit, capture, and communicate the voices of people who are directly affected by the injustice that is the focus of the social movement's activity. Some of the greatest pleasure I have known as a scholar and activist has come in situations where I was working to catch and pass on the words of people at the margin, ${ }^{21}$ people who have had direct experiences of injustice and who hold deep convictions about those experiences, but few channels through which to share or project them. Working as a scavenger for the framing enterprise of the plant-closing movement offered a chance at more of the same.

As things turned out, both sets of hopes were realized, at least in part, by later developments. The plant-closing movement did provide opportunities for direct learning and exchange with people who were undergoing economic crisis. In addition, many of us in that movement did find ways to disseminate results of those exchanges and thereby help frame the issues in public policy venues. ${ }^{22}$ The move-

movements because it will have a hard time producing results that actually help build a strong movement as opposed to a manipulable mass.

${ }^{21}$ Actually, catching the meanings of people at the margin is probably a more accurate, if not a more ambitious, way of saying what I mean. My most satisfying projects have included audio-visual communication that allows bodies, gestures, and environments to join with words in conveying meanings. See Videotape: From the Mountains to the Maquiladoras: A TIRN Educational Video (Tennessee Industrial Renewal Network 1993) (available through the Highlander Research and Education Center) (documenting a trip by Tennessee factory workers to visit maquiladora workers and organizers in the Reynosa-Matamoros region of northern Mexico in 1991). I am currently serving as principal humanities advisor to a documentary project under the direction of video-maker Anne Lewis. The eventual full-length documentary will look at the impacts of globalization on several communities in East Tennessee and in Mexico that are linked by dynamics of capital flight or emigration/immigration.

${ }^{22}$ See, e.g., Ansley, supra note 1, at 1889 (framing the issue as "[s]hould government continue to participate in the economy in the same way it has in the past, or should it begin to do so in a more humane, democratic and egalitarian way"); see also Fran Ansley, North American Free Trade Agreement: The Public Debate, 22 GA. J. INT'L \& COMP. L. 329 (1992) (introducing testimony regarding the pros and cons of NAFTA); Fran Ansley, The Gulf of Mexico, The Academy, and Me: Hazards of Boundary Crossing, 78 Soundings 69 (1995) [hereinafter Ansley, The Gulf of Mexico] (telling stories about the effects of increased economic integration between the United States and Mexico); Fran Ansley \& Susan Williams, Southern Women and Southern Borders on the Move: Tennessee Workers Explore the New International Division of Labor, in NEITHER SEPARATE NOR EQUAL: WOMEN, RACE, AND Class IN THE SOUTH 207 (Barbara Ellen Smith ed., 1999) (documenting focus group discussions between individuals involved in the TIRN program). Of course, the scholarly act of gathering stories and using them has its moral and intellectual hazards. What are the ethics of representation in this context? Who should speak for another and under what circumstances? What can reasonably ground claims of authenticity? And who decides any of this, anyway? Academic dilemmas aside, this question of voice is an issue of concern for the social movements themselves, 
particular framing project might end up being part of something big. ${ }^{19}$

Framingwork exerted a pull from another direction as well. While the "big ideas" of the plant-closing movement seemed like they might be generative ones capable of producing change at the highest levels of policy formation, it also was clear that successfully reframing the asserted rights of corporate decision makers to move their capital investments at will would require serious listening at the grassroots. This kind of movement would have to go to the people in its popular base, both to ask them what was on their minds, and to seek the power of their experiences and their rhetorical choices.

For a social movement to find an effective way of framing its issues, it must learn and attend to the narratives and images voiced by its own present and potential constituents. A frame cannot convince or engage unless it is culturally intelligible to its intended audience. It must strike them as consonant with their values and consistent with what they already understand about the nature of the world and the people in it. Granted, this imperative constitutes something of a paradox. By definition, the frame proposed by a social movement urges change: it seeks to move people out of their current stance and into new sorts of action. Nevertheless, to some extent a movement's framing efforts must draw from collective memories, past experiences, and existing belief structures of the movement's constituency in order to have mobilizing power.

This characteristic of framingwork makes it appealing to those interested, as I am, in grassroots democratic practices, since it can exert a kind of listening discipline on social movements and their leadership. $^{20}$ It also offers concrete tasks for professional and amateur eth-

${ }^{19}$ Snow and Benford make an interesting distinction between frames that are "restricted" and those that are "elaborated," characterizing the former as relatively rigid (and therefore somewhat resistant to being applied beyond their specific context of origin, citing the example of the nuclear freeze movement), and characterizing the latter as more suggestive, transferable, and generative (and therefore tending to produce echoes and spin-offs, citing the example of the U.S. civil rights movement of the 1960s). Snow \& Benford, supra note 11, at 139-40. I saw in the plant closing situation a setting that might be capable of generating an "elaborated" frame.

${ }^{20}$ Of course there are no guarantees that a movement's unavoidable need for roots in a popular base will necessarily produce excellent or principled listening disciplines. Movement organizers and rhetoricians can try to listen, but still can be blocked by their own mental and cultural "static" from understanding what is being said. Or, the whole endeavor can be reduced to the kind of extractive, manipulative listening that we get from political pollsters, marketing consultants, and demagogues. This latter kind of listening is self-limiting in the context of efforts to build democratic social 
ment also enjoyed some concrete successes in altering public policy. Achievements included stronger job security provisions in many collective bargaining agreements, limited legislative protection for workers affected by some types of plant closings, enhanced adjustment programs to help dislocated workers make smoother transitions after mass layoffs, and the creation of a network of labor and community activists who had made each other's engaged acquaintance and who were critical of the corporate attitudes and practices embodied in many plant-closing sagas.

By no stretch of the imagination did the plant-closing movement emerge victorious. In fact, some of the movement's original aspirations to reduce capital flight as a corporate behavior in U.S. industry appear now to have been poignantly-perhaps pathetically-naive. Many industries continued on a crash course of restructuring. They reorganized their production processes and their corporate structures in new post-Fordist ways that radically diminished job security. They engaged in a frenzy of mergers, acquisitions, and disaggregations. In addition, they exponentially escalated their use of co-production across national boundaries.

Foes of plant closings were soon forced to recognize the deep structural character and the broad global scale of the decisions we were trying to influence. Meanwhile, the economic and political clout of labor unions continued to decline, in part because the industries that were closing down were often those with the strongest union base, and in part because even when jobs stayed in the United States, the "threat effect" of globalization exerted severe downward pressure on labor's bargaining position. ${ }^{23}$ It was as if plant-closing foes began by trying to put out what they thought was a small kitchen grease fire, only to realize as their efforts continued that arsonists had set the blaze and already the basement was fully involved.

Nevertheless, despite the undeniable disappointments, the plantclosing movement did not go up in flames, metaphorical or otherwise.

at least for those that aspire to internal democracy and to the principle that ordinarily people should speak for themselves. In the context of this Article, I will do little more than note the challenge, but there is no denying that it is a substantial one.

${ }^{23}$ For more on the threat effect of increased capital mobility and on certain debates over how to measure it, see James M. Cypher, NAFIA's Lessons: From Economic Mythology to Current Realities, 26 LAB. STUD. J. 5, $10-11$ (2001). But see Raul Hinojosa-Ojeda et al., The U.S. Employment Impacts of North American Integration After NAFTA: A Partial Equilibrium Approach (Jan. 2000), available at http://naid.sppsr.ucla.edu/ (study published by UCLA's School of Public Policy and Social Research) (finding NAFTA's overall impact on American jobs to be relatively small). 
In fact, the movement and its attendant framing project flowed directly into several important successor currents, including the international agitation against neoliberal "free trade" regimes, college antisweatshop coalitions, state and local efforts to curb abuse of corporate subsidies and other development incentives, and the burgeoning patchwork of campus and community campaigns for a living wage. These new currents are, I believe, strategic ones for any serious effort to link social movements in the North with their counterparts in the South on any of the many issues of social justice and environmental sustainability raised by today's world economy. ${ }^{24}$

${ }^{24}$ For instance, themes and relationships forged in the plant-closing movement became the foundation for the labor-community coalitions that first stepped so dramatically into the public spotlight in Seattle in 1999. Organizations now active in the movement to challenge "free trade" include many that were active in the plant-closing movement, including labor, environmental and community-based organizations, and many groups involved with strategies for "alternative development." Increasingly, these groups are building transnational alliances and partnerships and exploring ways to function in transnational political spaces. See, e.g., Alianza Social Continental [Hemispheric Social Alliance], $a t$ http://www.asc-hsa.org (providing information about a collective effort between labor organizations and other citizen movements in the Americas to address issues of trade and economic integration). Of course, many analysts fiercely dispute this emergent movement's critique of free trade and neoliberalism. For defenses of the dominant development model, see DAN BEN-DAVID ET AL., SPECIAL STUDIES 5: TRADE, INCOME DISPARITY AND POVERTY 43 (2000) ("[T] rade liberalization is generally a strongly positive contributor to poverty alleviation ...."); and WORLD BANK, WORLD DEVELOPMENT REPORT 1995: WORKERS IN AN INTEGRATING WORLD (1995).

Organizations working on subsidy abuse and other aspects of "smart growth" and "high road strategies" include the national research and policy center Good Jobs First, in Washington, D.C. <www.goodjobsfirst.org>, the Center for Labor \& Community Research <www.clcr,org>, and local organizations like the Connecticut coalition of congregations, unions, and community groups called Good Jobs <www.goodjobsct.com>. Of course industry representatives and siting consultants disagree that recipients of subsidies should be subject to public accountability restraints and often resist efforts to impose them. See, e.g., Jon Pepper, A Pro-Business Political Agenda Helps Michigan's Star Shine Brighter, DETROIT NEwS, Nov. 1, 1995 (explaining how a pro-business political agenda including tax cuts and regulatory relief has made Michigan more attractive to industry making capital investment decisions).

On the living wage movements, see William Quigley, Full-Time Workers Should Not Be Poor: The Living Wage Movement, U. Miss. L.J. (forthcoming 2001). Some organizations that are active around living wage issues in communities include the Association of Community Organizations for Reform Now (ACORN) <www.livingwagecampaign.org> and the New Party <www.newparty.org>. For a webpage focused on one particularly vigorous campus-based campaign, see the site of Harvard's Living Wage Campaign $<$ www.hcs.harvard.ed // pslm/livingwage>. For a broad business-oriented critique of the whole living wage concept, see the Employment Policy Foundation's webpage $<w w w . e p f . o r g>$. In the interests of full disclosure, I should mention that I am active in a living wage campaign at my own workplace. Information about that effort can be found on the University of Tennessee Faculty Senate webpage 
Accordingly, my assessment today is that the plant-closing movement was an important phenomenon that produced praiseworthy ideas and energy that are still being felt. Nevertheless, it displayed a number of weaknesses and contradictions as well. Further, the continued rightward drift in U.S. and global economic discourse makes it all too evident that the movement did not succeed in replacing the dominant frames on questions of capital accountability or of democratic political authority over economic background rules.

Of course, the reasons for recent political and economic trends are many, and they hardly begin or end with the rhetorical choices of the plant-closing movement and its frameworkers. This Article treats the rhetorical moves and choices of the movement as worth examination, but not on the basis that these moves and choices were singularly responsible for the movement's failure to unseat the ascendant neoliberal frame. Although the plant-closing movement suffered material and ideological defeats, it also contributed to important partial victories, helping to ground and inspire the emergence of new internationalist movements and helping to imagine an emergent alternative frame. Today, this alternative world view continues to develop within the new global networks that are attempting to challenge the neoliberal gospel of free trade. Weaknesses and contradictions within the framing project of the plant-closing movement, therefore, have continuing salience for today's social movements and their frameworkers, who continue to work, at least in part, with the images, metaphors, and sometimes unexamined assumptions they have inherited or carried over from earlier times.

\section{Plant Closings AND DefEnSE of Community: FRAMING CAPITAL FLIGHT}

When the plant-closing movement was in full swing, energetic efforts to reframe plant closings in a way that would motivate people to protest and take action were a conspicuous feature of its work. Plantclosing activists arranged occasions when dislocated workers could recount their experiences and project their own seldom-heard views on the ethics of corporate decisions that had led to the closure of stillprofitable facilities in search of higher returns. Movement leaders and rhetoricians kept their ears and sensibilities open for turns of

<http://web.utk.edu/ senate/LivingWageFAQ.html> and on the webpage of United Campus Workers (an independent union of hourly workers recently formed on the Tennessee campus) <http://www.korrnet.org/ucw/>. 
phrase, previously forgotten or underappreciated narratives, and strong cultural expressions. We were seeking images, values, and memories capable of countering the neoconservative frame, which was then being so energetically and authoritatively promoted by the architects of the new economy. ${ }^{25}$ The movement worked to circulate vividly-told stories that were critical of current trends and to celebrate values that those stories implied or expressed. ${ }^{26}$

\section{A. A Domestic Introduction to Capital Flight}

The vast majority of plant closings that became targets of social movement activity were not instances in which a business was closing up shop altogether. Instead, they were situations where management had decided to move production from one location to another. Though some plant closings did involve the full-scale winding up of a business, those situations more often represented true business failure, or relatively small enterprises where the resources to support jobsaving alternatives were plainly limited or nonexistent.

Accordingly, when the plant-closing movement began to frame the issues, the question of unfettered capital mobility loomed large. Plant-closing activists were not arguing, of course, that all capital investment should remain forever frozen from some magic moment onward. Putting aside the thorny practical and theoretical questions of how to locate a defensible baseline, activists conceded that econo-

2:5 Among the most active frameworkers doing this kind of listening and retrieval work was historian, activist, and legal services lawyer Staughton Lynd. See generally LYND, supra note 2 (offering a history of the closing of steel mills in Youngstown, Ohio, by highlighting the individual stories of steelworkers); Staughton Lynd, Corporate Ruthlessness and Community Despair, LAB. UPDATE, Feb. 1981, at 3 (comparing the trend of closing steel plants to the urban renewal tactics in the $1950 \mathrm{~s}$ and $1960 \mathrm{~s}$ that buldozed entire city sections and relocated all its residents); Staughton Lynd, The Fight to Save the Sieel Mills, N.Y. REV., Apr. 19, 1979, at 37 (recounting the closing of four steel mills in Youngstown, Ohio, leiding to unemployment for 10,000 workers, representing a widely-recognized symbol for the effects of "corporate ruthlessness and economic death"); Staughton Lynd, The Cenesis of the Idea of a Community Right to Industrial Property in Youngstown and. Piltsburgh, 1977-1987, 74 J. AM. HIST. 926 (1987) (explaining the origins of the idea that a long-standing relationship between company and community should create a property right vested in the community). For an Appalachian film that uses interviews with mountain people to contrast absentee corporate practices of extraction and abandonment with selected local values of conservation and connection, see BEYOND MEASURE: Ap'AlACHIAN CULTURE AND ECONOMY (Appalshop 1994).

${ }^{2 t}$ Groups that worked to "service" this reframing and disseminating project included the Federation for Industrial Renewal and Retention (no longer in existence) and the Midwest Center for Labor Research (still active as the Center for Labor \& Community Research), and its publication, Labor Research Review (now discontinued). 
mies need some mobile capital. The question raised by plant-closing advocates, however, concerned the terms on which mobility would proceed. They argued that productive industrial facilities were the result of joint endeavors that had too often been conducted under conditions of unequal exchange. They contended that at a moment when a jointly-created investment was about to be liquidated through a plant closing, the rules of a well-ordered democracy should require accountability and transparency. They maintained that, at such a moment, some contextual reassessment of the entitlements among relevant stakeholders should properly be conducted to include not only the company's formal shareholders, but also employees and surrounding communities.

Corporations that departed for other jurisdictions with little notice, meager severance transfers, or without justifications that workers and community residents deemed to be morally or factually adequate, were accused of abandonment. Their actions were depicted as escape from prior commitments, as betrayal of community and its norms, and as irresponsible departure for alien pastures where the reasonable expectations of home could be ignored.

The accusation of selfish individualist escape from the legitimate demands of community became a common trope within the dialogue between worker-based movements and employers in the private sector. That trope was strongly reinforced by the experiences of the plant-closing movement when it turned to government in an attempt to invoke or create legal constraints on corporate shutdown decisions. Such turns to law were commonplace as the movement sought ways to stop or at least slow the rapid erosion of prior custom. Although the plant-closing movement frequently targeted private rather than state decision makers and although much of the rhetoric it developed was specifically aimed at corporate actors, ${ }^{27}$ it also framed plant closings as

${ }^{27}$ The plant-closing movement thus serves as one of many indications that it would be a mistake to think that social movements only emerge in the context of statefocused conflicts and campaigns. Examples of demands by plant-closing activists that were targeted directly at private corporations are legion. For example, plant-closing organizations demanded that corporations refrain from closing plants; that they pay compensation, preserve retirement benefits, or make other adjustments for the benefit of affected workers and their families; that they defray local government expenses occasioned by mass dislocation and depletion of the tax base; that they give assurances about future job security; that they provide truthful answers to questions triggered by behaviors that the movement began to identify as typical danger signs of impending closure; and that they sell their plants to worker or community investors. The organizations also took various kinds of actions in support of their demands. For instance, they marched on company headquarters, brought lawsuits against corporations under 
a responsibility of government. Plant-closing groups frequently demanded of government entities that they come to the aid of those harmed by economic dislocation. Targeting the state naturally meant that the movement's framing process was in part a struggle over competing visions as to the proper roles of government and law in the economy.

Plant-closing organizations sometimes called on government to provide a publicly-funded safety net that could break the personal falls of workers cast off by corporations in the restructuring process. ${ }^{28}$ They also called on government officials to change the legal framework in ways that the movement hoped would alter the behavior of corporate actors whose decisions and development strategies had to take into account legal background rules.

Groups and coalitions sometimes asked public officials to exert influence on voluntary corporate decision making, with moral suasion or material incentives aimed at convincing corporations to reconsider a rumored or announced move. At other times they sought municipal ordinances or state statutes that would-at least in the future-attach "strings" to any economic development subsidies given to businesses. They also called on elected executives to use legal tools already avail-

\footnotetext{
a blizzard of legal theories, organized petitions and letter-writing campaigns directed at company executives, sought enforcement of collective bargaining agreements, picketed individual job sites, and paid rowdy visits to the homes and places of work of targeted company executives. For a once-current collection of demands and actions focused on private corporations, see Ansley, supra note 1, at 1805-60.

${ }^{28}$ Most industrial workers already had access to the inherited safety net of unemployment insurance. This system was, of course, vastly superior to the welfare system, which was the only safety net available to workers employed in many jobs outside the industrial sector or at its ragged fringes. See generally Nancy Fraser \& Linda Gordon, Civil Citizenship Against Social Citizenship?, in THE CondiTION of CITIZENSHIP 90 (Bart van Steenbergen ed., 1994) (arguing that welfare should be characterized as an expression of "social citizenship" compressing the themes of equality, shared responsibility, and public participation); Lucy A. Williams, Unemployment Insurance and Low-Wage Work, in HARD LABOR: WOMEN AND WORK IN THE POST-WELFARE ERA 158 (Joel F. Handler \& Lucie White eds., 1999) (arguing that unemployment insurance policies are value-laden inasmuch as low-wage workers, and particularly mothers, are excluded from less stigmatized forms of assistance and are forced, instead, to welfare). Although unemployment insurance was superior to welfare, it was still glaringly inadequate, especially in situations where an entire community was undergoing the shock of mass layoffs. Accordingly, the plant-closing movement sought government help at both state and federal levels, often in the form of extended unemployment benefits or jobtraining subsidies, to cushion the effects of dislocation. See, e.g., Economic Dislocation and Worker Adjustment Assistance Act, 29 U.S.C. $\$ \$ 1651-1662 c$ (1994) (mandating the establishment of a rapid response capacity administered by "dislocated worker units" within state governments that could plan for job training and other services and could seek alternative uses for abandoned facilities).
} 
able to them to enforce obligations linked to subsidies that had been given in the past. Sometimes they asked for direct legislative constraints on future shutdowns, measures that would require things like notice, good-faith bargaining, information sharing, job portability, or the payment of severance benefits to workers or local governments before a corporation could legally close a profitable industrial facility. Other times they asked the government to save industrial capacity by exercising eminent domain.

Activists looking for support from the state turned to the judicial branch as well. They combed through common law and statutory sources for existing causes of action that might protect their interests. When none were found, they asked courts to make new law in recognition of unprecedented events. In either case, they hoped that successfully litigated cases would provide not only material relief, but also official reinforcement for the movement's way of framing the issues.

In these varied efforts to enlist the aid of the state, the movement chalked up some modest successes. ${ }^{29}$ For instance, it won a scattering of plant-closing ordinances and statutes aimed at controlling subsidy abuse, ${ }^{30}$ it allied with administrators in some locations to begin monitoring the costs and benefits of development incentives," and it convinced some local officials to bring suit against departing employers. ${ }^{32}$ In the federal arena, despite vastly overheated opposition and a presidential veto, the movement helped win eventual passage of the

29 For a once current collection of preventive approaches to plant closings undertaken by government entities, usually in response to pressure from labor and community groups, see Ansley, supra note 1, at 1863-83.

See Roger KERSON \& GREg LeRoy, STATE AND LOCAl INITIATIVES ON Development Subsidies and Plant Closings (1989) (reviewing "recent state and local initiatives in two areas: plant-closing legislation and restrictions on economic development subsidies for private employers"); GREG LEROY, NO MORE CANDY STORE: States AND Cities MAKING Job SubSidies ACCOUNTABle (1994) (examining state and municipal right-to-know laws and public participation mechanisms that enable government agencies and potentially affected people to scrutinize subsidy proposals and monitor their progress).

31 See Edward V. Regan, Government, InC.: Creating accountability for ECONOMIC DEVELOPMENT PROGRAMS (1988) (providing examples of governments that establish accounting standards to enable assessment of the costs and benefits of economic development projects and a department designed to analyze projects and oversee the realization of their objectives).

${ }^{32}$ Denis Collins, Plant Closings: Establishing Legal Obligations, 40 LAB. L.J. 67, 72-79 (1989). But see Jonathan D. Glater, For Last Paycheck, More Workers Cede Their Rights to Sue, N.Y. Times, Feb. 24, 2001, at A1 (discussing a trend among employers when laying off workers to make severance payments conditional on signing away the right to sue the employer). 
Worker Adjustment and Retraining Notification Act (the "WARN Act") in the U.S. Congress. ${ }^{33}$

On the whole, plant-closing groups were probably less successful in their appeals to the judiciary than in their appeals to legislators, but occasionally the combined force of dramatic events, sweeping injury, and persuasive framingwork resulted in courtroom victories as well. Despite the best efforts of movement lawyers, litigated plant-closing cases typically ended up turning on fine points or technical legal questions that bracketed out the kinds of fundamental questions usually involved in framing contests. Nevertheless, in some instances, litigation provided a public stage where judges allowed a wider scope and even sometimes became significant contributors themselves to an attempted re-framing process. Perhaps these examples stand as their own kind of evidence that the level of social upset over plant closings was something extraordinary, at least in the industrial heartland.

For instance, in an Ohio lawsuit in 1980, federal district Judge Thomas D. Lambros briefly granted a temporary injunction when social-movement plaintiffs sought to restrain the closing of U.S. Steel's last large steel works in the Mahoning Valley. In granting the injunction, Judge Lambros observed:

Everything that has happened in the Mahoning Valley has been happening for many years because of steel. Schools have been built, roads have been built. Expansion that has taken place is because of steel. And to accommodate that industry, lives and destinies of the inhabitants of that community were based and planned on the basis of that institution: Steel.

But what has happened over the years between U.S. Steel, Youngstown and the inhabitants? Hasn't something come out of that relationship, something that out of which-not reaching for a case on property law or a series of cases but looking at the law as a whole ... and then sitting back and reflecting on what it seeks to do, and that is to adjust human relationships in keeping with the whole spirit and foundation of the American system of law, to preserve property rights . . . It would seem to me that when we take a look at the whole body of American law and the principles we attempt to come out with-and although a

${ }^{33} 29$ U.S.C. $\$ \$ 2101-2109$ (1994) (requiring notice to employees, their representatives, and designated government officials before mass layoffs). The WARN Act continues to be an important if extremely limited protection for workers hit by plant closings. The Guild Law Center <www.sugarlaw.org> in Detroit, Michigan, has provided legal counsel to many workers affected by plant closings, and also publishes the WARN Act Practitioner's Guide. 
legislature has not pronounced any laws with respect to such a property right, that is not to suggest that there will not be a need for such a law in the future dealing with similar situations-it seems to me that a property right has arisen from this lengthy, long-established relationship between United States Steel, the steel industry as an institution, the community in Youngstown, the people in Mahoning County and the Mahoning Valley in having given and devoted their lives to this industry.

Although Judge Lambros ultimately declined to issue a permanent injunction, his words in this context were widely noted at the time, and they serve as a kind of high-water mark of reframing during the period when the U.S. steel industry was dismantling much of its thenexisting infrastructure.

A later case provides another example of a judicial contribution to the framing process, this time in the context of a challenge to subsidy abuse. In 1993, Judge Shelton, a circuit court judge for Washtenaw County, Michigan, granted an injunction against General Motors' plan to move production of its Caprice automobile from Ypsilanti, Michigan, to Arlington, Texas. The company planned to make this move despite having received millions of dollars in tax abatements on the strength of its earlier assurances to city officials at a public meeting that if granted the abatements, it would not transfer production from Ypsilanti to another location. The court's injunction was overturned on appeal, but in his original order, Judge Shelton observed:

The relationship of government and industry in this country is necessarily one of conflict, for it is the purpose of government to provide for the common welfare of all and it is the antithetical purpose of an industry to strive solely for the profit of its owners. For example, contrary to the approach of the defendant in this case that "what is good for General Motors is good for the country," the truth is, as this case demonstrates, that what is good for General Motors may only coincidentally help, and often hurts, many of our people. Industry is the source of many of the jobs in

${ }^{34}$ Joseph William Singer, The Reliance Interest in Property, 40 STAN. L. REv. 611, $618-$ 19 (1988) (quoting Judge Lambros's statements from transcripts of pretrial hearings as they appear in United Steelworkers, Local 1330 v. United States Steel Corp., 492 F. Supp. 1, 6 (N.D. Ohio), affd 631 F.2d 1264 (6th Cir. 1980) (footnotes and emphasis omitted)).

${ }^{35}$ For a view of this case and its surrounding context from inside the courtroomand from inside the social movement that then raged among steelworkers and local communities in the Mahoning Valley-see I.YND, supra note 2, at 141-89. For other commentary on Local 1330, see Daniel A. Farber \& John H. Matheson, Beyond Promissory Estoppel: Contract Law and the "Invisible Handshake", 52 U. CHI. L. REv. 903, 938-45 (1985); and Duncan Kennedy, Distributive and Paternalist Motives in Contracl and Tort Law, with Special Reference to Compulsory Terms and Unequal Bargaining Power, $41 \mathrm{MD}$. L. REV. 563, 630-31 (1982). 
our nation and it may well be that our nation needs a new relationship of trust and cooperation between government and industry in order to compete with heavily subsidized industries from other ... countries.

But such an effort must be national in scope and must be a real partnership with industry, not one in which industry simply views government as part of its "business climate" and another opportunity to increase profits. The tax abatement statutes in this State and others are not the product of a well thought out effort to forge such a new partnership. This tax subsidy policy results in pitting state against state and municipality against municipality.... The local governments of this State are placed in a position where they feel that they have no choice but to give taxpayers" resources away under a statute which does not mandate that they receive anything in return for those foregone taxes ....

There would be a gross inequity and patent unfairness if General Motors, having lulled the people of the Ypsilanti area into giving up millions of tax dollars which they so desperately need to educate their children and provide basic governmental services, is allowed to simply decide that it will desert 4500 workers and their families because it thinks it can make these same cars a little cheaper somewhere else. Perhaps another judge in another court would not feel moved by that injustice and would labor to find a legal rationalization to allow such conduct. But in this Court it is my responsibility to make that decision. My conscience will not allow this injustice to happen. ${ }^{36}$

Needless to say, in the context of legal challenges to plant closings, there was plenty of judicial rhetoric taking another direction altogether, a direction that endorsed (and enforced) the predominant frame. ${ }^{37}$ Meanwhile, defenders of "flexible" production and corpo-

${ }^{36}$ Charter Township of Ypsilanti v. General Motors Corp., 8 Individual Emp. Res. Cas. (BNA) 385, 393-95 (Mich. Cir. Ct. Feb. 9, 1993) (footnotes omitted), rev'd, 506 N.W.2d 556 (Mich. Ct. App. 1993). I should note that I helped to draft an amicus brief filed on behalf of the Federation of Industrial Renewal and Retention (FIRR) in opposition to General Motors' ultimately successful appeal of Judge Shelton's order. See infra note 37 (discussing the subsequent history of the case).

${ }^{37}$ On appeal in the Ypsilanti case, for instance, the court opined:

The trial court's finding that defendant promised to keep Caprice and station wagon production at Willow Run is clearly erroneous. First, the mere fact that a corporation solicits a tax abatement and persuades a municipality with assurances of jobs cannot be evidence of a promise. The very purpose of tax abatement legislation is to induce companies to locate and to continue business enterprises in the municipality ... .

Second, representations of job creation and retention are a statutory prerequisite. An applicant for an industrial facilities exemption certificate must, among other things, certify that "[c]ompletion of the facility is calculated to, and will at the time of issuance of the certificate have the reasonable likelihood to create employment, retain employment, prevent a loss of employment, or 
rate freedom were quick to provide their own spin. In most instances, corporations tried to cast state-centered demands by the plant-closing movement as ill-advised attempts to induce government interference with the natural functioning of the market.

This laissez-faire line of argument may have appeared hypocritical when advanced by the same corporations that were quick to demand or accept government subsidies and development incentives, but the inconsistency did not deter them from invoking the powerful free market frame. In many cases, high-toned calls to free market principles were coupled with open or veiled threats of raw power. ${ }^{38}$ Companies frequently announced that they would take their production elsewhere even more rapidly, completely, or irrevocably than otherwise if a government entity imposed unwanted rules or refused to provide desired benefits.

These threats promoted regulatory competition, a practice that constituted one of the most powerful obstacles the plant-closing movement faced when it tried to persuade governments to impose stronger popular controls on capital mobility. Local and state governments were acutely aware of the fierce contest to attract scarce investor dollars in an environment where it had become both easier and more profitable to withdraw and move investments with great frequency. Under these circumstances, government officials were often pressed into a race to see which jurisdiction could and would create the most "business friendly" regulatory climate.

I dwell at some length on these efforts of the movement to invoke the aid of the state because I believe its experiences in this arena played a part in producing the dilemma $\mathrm{I}$ intend to describe below.

produce energy in the community in which the facility is situated." . .

Third, the fact that a manufacturer uses hyperbole and puffery in seeking an advantage or concession does not necessarily create a promise...

The acts cited by the trial court were acts one would naturally expect a company to do in order to introduce and promote an abatement proposal to a municipality. The acts did not amount to a promise and, as course-of-conduct evidence, showed only efforts to take advantage of a statutory opportunity. They did not constitute assurances of continued employment. ...

....

Even if the finding of a promise could be sustained, reliance on the promise would not have been reasonable.

Ypsilanti, 506 N.W.2d at 559-61 (citations omitted).

${ }^{38}$ For a mild example, see James B. Treece et al., States Now Want a Money-Back Guarantee, Bus. WK., Sept. 21, 1992, at 35, 36 ("Rarely do our clients accept these penalty clauses .... They get negotiated out, or they go elsewhere."). 
The movement's attempts to use law reform to combat plant closings, and the threat of capital withdrawal that was used so effectively against it in these efforts, began to paint a vivid picture for plant-closing activists about lawmaking and power. These experiences brought home to us the need for effective democratic authority-for popular and potent jurisdiction, if you will-over the economic agents active in a given polity. If the electorate wanted the ability to adopt and revise background rules for the functioning of labor markets, then the ability to enforce a containing boundary began to seem essential. These experiences also showed just how hard it would be to establish or retain such authority when capital could force or entice different polities into competition with each other.

As I worked in and with the plant-closing movement, I began to distill lessons from our encounters with departing investors and with the timidity of government entities in responding to capital flight. I saw the process as one that drained vitality from democratic governance. In retrospect, I think a formulation something like the following began to guide and inspire many of my rhetorical choices:

\section{The Dilemma, First Pole $\left(\mathbf{P}_{1}\right)$}

Social movements interested in strong democracy must assert and defend the holding power of political boundaries, because in a globalizing world, the erosion of a polity's jurisdictional bounds renders democratic social disciplines toothless, increases inequality, and fortifies economic privilege.

Many of the material moves and ensuing ideological battles that lay beneath this distillation were played out on a domestic stage, among contesting U.S. jurisdictions that were advantaged or disadvantaged by various differences-political, regional, racial, and otherthat had been produced by the country's uneven development path. For instance, deindustrialization of urban core locations where the workforce was heavily African-American reached epidemic proportions, and its severe consequences were noted with alarm by scholars concerned about poverty and race." The Ypsilanti opinion quoted

39 See, e.g., William Julius Wilson, The Declining Significance of Race: BLACKS AND CHANGING AMERICAN INSTITUTIONS 92-99 (2d ed. 1980) (examining the relationship between the decentralization of business and high African-American unemployment rates); John M. Jeffries \& Richard McGahey, Equity, Growth and Socioeconomic Change: Anti-Discrimination Policy in an Era of Economic Transformation, 13 N.Y.U. REV. L. \& SOC. CHANGE 233 (1984-85) (documenting the harsh impact of the changing economy upon African Americans to substantiate the need for significant anti- 
above provides an instructive example of domestic competition. In that dispute, General Motors played a whipsaw game that pitted union members and their community outside of rust-belt Detroit against another United Auto Workers local and another very different community outside of Sun Belt Dallas.

\section{B. Maquiladoras and NAFTA Open a Window to the World}

As time went on, however, the movement encountered more and more cases where production was being shifted not simply from inner cities to suburbs, from the industrial heartland to greenfield locations in right-to-work states, or from one in-state location to another in response to a sweeter deal. Instead, production was moving out of the country altogether, often bound for low-wage locations in nations of the global South. The maquiladoras in particular, located so close to the United States, strung out along the northern tier of Mexican states fronting the U.S.-Mexico border, drew increased attention from plantclosing activists and became the topic of animated discussion and apprehension. $^{40}$

When first President George H.W. Bush and then President Clinton took up the banner of the North American Free Trade Agreement (NAFTA), this complex of issues about capital mobility and democratic governance became focused more than ever at the national and international level. ${ }^{41}$ Plant-closing veterans were exqui-

discrimination efforts); Gregory D. Squires, "Runaway Plants," Capital Mobility, and Black Economic Rights, in Community and CaPital in Conflict: Piant Closings and JOB Loss 62 (John C. Raines et al. eds., 1982) (exposing the negative impact of the post-World War II economy on African-American workers and communities).

40 For examples of early reports on the maquiladora phenomenon, and on similar export-processing zones in other parts of the global South, see MARIA PATRICIA FERNANDEZ-KELly, FOR WE ARE SOLd: I AND MY PEOPLE-WOMEN AND INDUSTRY IN MEXICO'S FRONTIER 70-90 (1983); RACHAEL KAMEL, THE GLOBAL FACTORY: ANALYSIS AND ACTION FOR A NEW ECONOMIC ERA (1990); LESLIE KOCHAN, THE MAQUILADORAS AND TOXICS: THE Hidden COSTS OF PRODUCTION SOUTH OF THE BORder 10-12 (1989); and Mary E. Kelly \& Richard Lowerre, The Maquiladora Boom on the TexasMexico Border: Environmental and Public Health Implications and Potential Legal Remedies (June 1990) (unpublished manuscript, on file with author).

${ }^{41}$ The issue was a national one, but its impacts were not restricted to the federal government's activities. State and local governments became increasingly aware and worried about the impact of free trade agreements on their ability to make policy. See, e.g., Robert Stumberg, Balancing Democracy \& Trade: State/Local Roles in the Global Trade Debate (Sept. 28, 2000) (unpublished paper prepared for the Legislative Committee on Economic Development of the Washington State Legislature) (on file with author) (presenting reasons why global agreements are both a state and local concern and suggesting appropriate roles for state and local government in matters of global 
sitely primed to see the dangers and the deep power contests embedded in laws that governed and protected freedom of movement for capital. They saw free trade deals as the locking-in of exactly the rules and practices they had been trying so hard to fight, and many plantclosing activists were quick to involve themselves in the emerging mobilizations against NAFTA and free trade.

NAFTA made an easy target because it posed specific and facially evident threats to democracy in two ways. First, it was thought (probably correctly) to be unratifiable in the absence of "fast-track" authority, and the executive branch therefore launched an aggressive campaign to win that special set of powers from Congress. The powers and procedures involved in fast-track legislation impose time limits on congressional debate at the ratification stage of trade agreements, and also require that a trade agreement be voted up or down as a whole, with no opportunity for the ordinary process of congressional amendment, bargaining, negotiation, and debate. To opponents, this exceptional procedure exemplified NAFTA's anti-democratic promise. $^{49}$

In addition to fast-track's deviation from normal congressional procedure for ratifying trade deals, NAFTA imposed prospective substantive limits as well-limits that constrained the exercise of legisla-

trade policy); Thomas Singer \& Paul Orbach, Multilateral Agreement on Investment: Potential Effects on State \& Local Government (1997) (unpublished report to the Western Governors' Association) (examining the implications of a public proposal for the Multilateral Agreement on Investment for sovereignty of state governments, and recommending actions for state governors), available at http://www.westgov.org/ WGA/publicat/maiweb.htm.

${ }^{42}$ The second Bush administration has rechristened fast-track in an apparent effort to make it more palatable to the American public. The current term employed is "trade promotion authority." Will Bush Fight for Free Trade?, ECONOMIST, June 23, 2001, at 25.

${ }^{43}$ Proponents argued otherwise. They pointed out that, like Congress, the President is an elected official. They also argued that trade negotiations are complex deals that are carried out by diplomatically trained officials. Accordingly, their delicate and heavily negotiated architecture should not be subjected to the push and pull of ordinary congressional politics, because such agreements will almost certainly come unraveled, to the detriment of everyone. Besides, they maintained, the President only receives fast-track authority with the approval of an elected Congress, so hand-wringing over erosion of congressional authority is misleading and misplaced. For a similar suggestion about the currently proposed Free Trade Area of the Americas, see Editorial, Trade $\mathcal{E}$ Democracy: Summit of the Americas Focuses on Energy, Expansions of Current Pact, KNOXVille News-Sentinel, Apr. 24, 2001, at A10, calling for approval of fasttrack, and pointing out that all thirty-four leaders of the FTAA nations are "democratically elected" and that the deal included "a democratic clause that effectively made democracy a condition of a nation's participation in trade talks." 
tive power in the signatory countries. ${ }^{44}$ For instance, under NAFTA, governments can be sanctioned for giving preference to domestic products or for using human rights criteria in government purchasing, and, under the rubric of assuring fairness and stability to foreign investors, a host of other often ill-defined prohibitions are imposed.

Governments are forbidden to adopt a range of "performance requirements" on foreign capital, a prohibition that arguably could prohibit measures that encourage or require foreign investors to seek out local suppliers, hire local residents, recirculate locally made profits, or actively promote "back linkages" between the foreign-financed production process and local industry. ${ }^{45}$ Governments are forbidden to limit repatriation of profits or to require that foreign investment remain in the jurisdiction for any particular period of time. ${ }^{40}$ They are also prohibited from effecting what in U.S. constitutional parlance would be called "regulatory takings." That is, NAFTA provides that signatory governments may be found liable for trade infractions not only if they move to confiscate an asset or to take title to property of a foreign investor, but also if they enact regulations on corporate activity that come to be seen as "tantamount" to "expropriation" or as constituting "indirect" expropriation. The operative outlines of this potentially far-reaching limitation in the context of global trade law are no clearer than they are in current U.S. takings jurisprudence, and the potential scope is similarly sweeping. ${ }^{47}$

${ }^{44}$ See North American Free Trade Agreement, Dec. 17, 1992, U.S.-Can.-Mex., 32 I.L.M. 289, 639 (1993) [hereinafter NAFTA] (outlining the substantive restraints of Chapter 11, Section A, of the agreement relating to investments and the restraints on each party as to issues ranging from national treatment requirements to environmental measures), available at $\mathrm{http}: / /$ www.nafta-sec-alena.org/english/nafta/nafta.htm.

${ }^{45}$ NAFTA and similar agreements are thus in ideological tension, and perhaps in legal conflict, with such measures as the federal Community Reinvestment Act. See, e.g., Public Citizen, Does the Proposed Multilateral Agreement on Investment (MAI) Threaten Community Reinvestment Laws? at http://www.citizen.org/pctrade/otherissues/MAI/ what\%20is/commmai.htm (last modified Aug. 22, 1997) (arguing that policies allowing foreign corporations to sue governments for infringing on their right to invest will counteract economic development plans).

${ }^{46}$ NAFTA, supra note 44 , ch. 11 , art. 1106, 32 I.L.M. at 640.

${ }^{47}$ See id., ch. 11, art. 1110, 32 I.L.M. at 641 (providing in part that "no Party may directly or indirectly nationalize or expropriate an investment of an investor of another Party in its territory or take a measure tantamount to nationalization or expropriation of such an investment" unless it pays compensation, provides due process, does not discriminate between investments of domestic and foreign investors, and is acting to promote a public purpose (emphasis added)).

One commentator has argued that warnings about the potentially sweeping definitions of expropriation under Chapter 11 are overblown because there is an existing body of international law that has already staked out some reasonably clear and justi- 
Meanwhile, NAFTA's new rights for international investors are supported by powerful new remedies. Trade sanctions, such as countervailing duties, may be invoked by aggrieved governments. More radically, however, NAFTA also created unprecedented avenues by which private corporations themselves may invoke dispute-settlement proceedings against sovereign governments for allegedly violating investor rights set out in the agreement. ${ }^{48}$ Although similar language on indirect expropriation has been a feature of bilateral investment treaties for some time, ${ }^{49}$ these new investor-to-state dispute settlement procedures break new ground in creating a corporate right of action. Monetary compensation may be ordered in favor of a complaining corporation if a legislative body or other government official or entity in one of the member nations is held to have overstepped the new prohibitions announced in the NAFTA text, as that text comes to be interpreted by the elite international dispute-resolution panels created and empowered by it.

From the perspective of the world's poorer countries, Mexico included, the experience of having one's domestic economic policy dictated by foreign investors or by a foreign government's economic policies was nothing new. From the days of bald colonial imposition

fied parameters. See Jason L. Gudofsky, Shedding Light on Article 1110 of the North American Free Trade Agreement (NAFTA) Concerning Expropriations: An Environmental Case Study, 21 NW. J. INT'L L. \& BUS. 243, 244 (2000) (“[D]oomsday predictions are without substance or merit."). This reader, for one, however, was not particularly reassured to peruse the following list, offered by the author as illustrative of the kinds of government action that might be considered sufficiently "expropriatory" to require compensation:

unreasonable taxation ... certain cases of zoning ... unreasonable price ceilings ... the setting of local wages at prohibitively high rates ... the appointment of . . . inspectors who substantially impair the free use by the alien of his premises and facilities... unreasonable contract renegotiation ... prohibition of gainful activity previously lawfully engaged in ....

Id. at 259 n.41 (quoting CYNTHIA DAY WALLACE, LEGAL CONTROLS OF THE MULTINATIONAL ENTERPRISE 277 (1983)). The author's offer of a general rule of thumb about what will constitute an "indirect expropriation" under NAFTA's Chapter 11 was no more reassuring. See id. at 286 . Gudolsky further states:

Generally speaking, a measure enacted or adopted by a government will not amount to a compensable injury on the basis of an indirect expropriation unless the measure is unreasonably substantial or otherwise has more than an ephemeral impact on the ability of the property owner to use and enjoy his or Id. her property.

48 NAFTA, supra note 44, ch. 11, sec. B, arts. 1115-38, 32 I.L.M. at 642-47.

49 See Rudolf Dolzer \& Margrete Stevens, Bilateral InVEstment Treaties 97-117 (1995) (analyzing the requirements imposed by investment treaties upon countries trying to expropriate foreign investments). 
to more recent experiences with the debt crisis and structural adjustment programs imposed on debtor states by international financial institutions, such countries have been made acutely aware of the ways that global economic actors, both private and governmental, can limit an individual government's national policy options. ${ }^{50}$ For many people in the United States, however, including many participants during the heyday of the plant-closing movement, the prospect of our national government having to take orders from international actors and entities came as something of a shock. ${ }^{51}$ NAFTA thus served as a nightmarish vindication of the warnings that had been sounded so strongly by the plant-closing movement about the potential impacts of unaccountable capital mobility on democratic governance. The political threat implied by the increasing incidence of capital flight now seemed fully demonstrated.

As the plant-closing movement and its allies moved into the arena of trade policy, I therefore continued to draw on the lessons and in-

${ }^{50}$ Southern critics of neoliberal "free trade" agreements have long stressed the impact of those agreements on the autonomy of poorer countries and on their ability to frame their own plans for economic development. For an eloquent early example of this developing critique, see CHAKRAVARTHI RAGHAVAN, RECOLONIZATION: GATT, THE URUGUAY ROUND \& THE THIRD WORLD 45 (1990). The contemporary constraints on national economic policy that were applied to countries in the global South predated the recent rash of free trade agreements. Because so many of those countries were laboring under a staggering debt burden, they were forced to seek the aid of international financial institutions such as the IMF and the World Bank, and these institutions were therefore in a position to impose strict conditionalities on the aid they provided. Those conditionalities for the most part concentrated on assuring that the governments in question adopted the free trade and free market gospel of neoliberal economic policy, often in the form of "structural adjustment programs," or SAPs.

51 Most people in the United States are still unaware of these pressures on the world's debtor countries or their collision with untrammeled national legislative authority. One precondition for northern participation in any kind of broad movement for "globalization from below" will be for people in northern social movements to gain basic literacy in these matters. Many social movement organizations in the North are now working to develop popular education materials that will help achieve this kind of literacy, but the task is huge and the efforts only now beginning. See, e.g., Miriam Ching LOUIE \& Linda BURnhaM, WOMEN'S EdUCATION IN THE GLOBAI ECONOMY: A WORKBOOK (2000) (available from the Women of Color Resource Center) (describing the problems faced by women in the move toward a global economy and how they are organizing to protect their rights); ECONOMIC LITERACY ACTION NETWORK, UNPACKING GLOBALIZATION: A POPULAR EDUCATION TOOL KIT (2000) (presenting a collection of educational materials designed to help people understand globalization and its effects on multiple aspects of their lives), available at http://www.hrec.org/pdfiles/hc.collections.catalogueoct00.pdf; United for a Fair Economy, Globalization for Beginners (describing workshops led by the organization, as well as the organization's "do-it-yourself kit," both designed to educate about globalization), at http://www.ufenet.org/econ/globalization.html (last visited Nov. 29, 2001). 
sights I have tried to capture above as $P_{1}$. I attempted to intervene convincingly in public discourse, and $I$ invoked " $P_{1}$ thinking" in settings where issues of economic development, free trade, and globalization were being discussed. For instance, more than once I have spoken with audiences about what I described as a proud and hardwon heritage of American precedents upholding the authority of the electorate over economic ground rules. I have shared stories of origin about these precedents, telling how Americans were able to use the instruments of popular democracy to win them. I have gone on to ask with alarm how we expect the democratic will of the people to exert similar authority over new global trade rules, since these new regimes are being created and administered "out there" in the transnational wilderness, beyond the legal reach of our contentious national polity and its jurisdictional bounds. ${ }^{52}$ I have warned listeners and readers that the organs of democracy are being weakened through the breakneck expansion of global legal structures that are crafted and staffed by corporate-oriented experts in business and law, freighted with free trade rules that strengthen the hand of international capital, and accountable to no electorate anywhere on earth. ${ }^{53}$

${ }^{52}$ For example, I have argued that the defeat of the infamous Lochner case was a popular victory made possible by combined pressures from an elected President and Congress, from popularly elected state governments, and from the general mood of national public opinion during the Great Depression-all hugely affected, of course, by the upsurge in labor- and community-based social movement agitation that characterized that era. Frances Lee Ansley, Rethinking Law in Globalizing Labor Markets, $1 \mathrm{U}$. PA. J. LAB. \& EMP. L. 369, 415-17 (1998). I have claimed that because of its access to democratic political channels and its ability to express itself in public debate, the American electorate was able to triumph over the constitutionalization of American laissez faire that the Supreme Court imposed under the guise of "freedom of contract." Id. I have observed that the victory over Lochner legitimated and cleared the way for the radically more democratic New Deal. See Lochner v. New York, 198 U.S. 45 (1905), holding that the New York law prohibiting bakers from working more than sixty hours per week was an unconstitutional exercise of the state's police powers because the law was an impermissible interference with individual contract rights, and the case that announced its demise, NLRB v. Jones $\mathcal{E} 0$ Laughlin Steel Corp., 301 U.S. 1, 37 (1937), holding that Congress has the power to regulate activities that have a "close and substantial relation to interstate commerce," including labor disputes. I have gone on to point out that it is difficult to discern similar democratic levers at a global level that would allow the mass of people now governed by free trade agreements to voice, whether directly or indirectly, their considered disapproval of today's global laissez faire, imposed by an unaccountable global elite under the guise of "free trade."

${ }^{53}$ Ansley, supra note 52, at 415-27 (stressing that even domestic issues, such as the low-wage job market and anti-poverty policies, "are part of a much bigger set of developments [such as, economic globalization] that the U.S. electorate could not dream of controlling"); Frances Ansley, What's the Globe Got to Do with It? Afterword to HARD LABOR: WOMEN AND WORK IN THE POST-WELfARE ERA 207, 216 (Joel F. Handler \& Lu- 


\section{Fears About Internationalized Capital Flight Confirmed}

I am far from abandoning $P_{1}$ thinking as a source of inspiration and guidance for framingwork with contemporary social movements. In fact, the plant-closing movement's fears about the dangers of NAFTA at the time of its passage have only been exacerbated by subsequent events. The track record of claims brought thus far under its investor-state settlement provisions is sobering. ${ }^{54}$ In most of the disputes, the information available to the public is sparse, but whatever the facts and merits of a particular claim, the overall record to date is more than adequate to reveal the potential reach of NAFTA's legislation-restricting rules. If these provisions are given an expansive reading, they will constitute radical new regulations imposed on the democratic political process in the interests of transnational corporate owners. The types of claims filed by multinational corporations, the aggressiveness with which claimants are pushing the relevant legal categories, the absence of the reciprocal diplomatic restraint that of-

cie White eds., 1999) (“[P]roponents of this freedom and openness [for global trade] are at work constructing legal regimes that are filled with constraints on the ability of states to follow the will of their electorates if that will diverges from the dictates of the economic model that animates present corporate strategies.").

${ }^{54}$ NAFTA's remarkable investor rights provisions are found primarily in Chapter 11 of that agreement. The full text of NAFTA is available through, inter alia, the website of the tri-national NAFTA Secretariat, at http://www.nafta-sec-alena.org/ english/index.htm. Limited information on some pending and settled disputes handled under mechanisms set out in Chapter 11 is available on the website of the World Bank's International Centre for the Settlement of Investment Disputes (ICSID), at http://www.worldbank.org/icsid/cases/cases.htm.

For a critical discussion of Chapter 11 and a digest of known Chapter 11 cases, current as of March 1, 2001, see Howard ManN, Private Rights, Public Problems: A GUIDE TO NAFTA's CONTROVERSIAL CHAPTER ON INVESTOR RIGHTS (2001), available at www.iisd.org/trade/pdf/trade_citizensguide.pdf. Note that the appended digest, like other private collections, is particularly helpful to researchers because the unprecedented investor-to-state dispute settlement processes created under Chapter 11 allow only limited public access to the written documents filed in the proceedings, and no public access at all to the proceedings themselves. As a result, matters that a lawtrained researcher is likely to regard as part of the "normal record" of legal proceedings are often not available in NAFTA Chapter 11 cases.

For an astute assessment of Chapter 11's tendency to privilege transnational businesses and U.S. interests despite its facial neutrality, see José E. Alvarez, Critical Theory and the North American Free Trade Agreement's Chapter Eleven, 28 U. MiAMI INTER-AM. L. REV. 303, 305 (1996-97). For an enthusiastic description of Chapter 11 that praises its reasonableness and argues that its expropriation provisions build soundly and modestly on existing international law, see Gudofsky, supra note 47 . For a Canadian view that Chapter 11 may bring about a conflict with the Canadian law on "expropriation" versus "regulation," see Donald S. Macdonald, Chapter 11 of NAFTA: What Are the Implications for Sovereignty?, 24 CAN.-U.S. L.J. 281 (1998). 
ten tempers state-to-state disputes in international trade matters, and the lack of access or accountability to democratic electorates that is evident in the whole structure of NAFTA's Chapter 11 dispute resolution mechanisms are all factors that indicate the danger to democracy posed by the neoliberal trade regime. ${ }^{5 i}$ A handful of examples, each involving a claim against a different NAFTA partner, will illustrate such problems.

In one of the earliest NAFTA cases, a U.S.-based multinational energy company, the Ethyl Corporation, sued the government of Canada for $\$ 250$ million after the Canadian Parliament banned the import of "MMT" into Canada." The Ethyl Corporation claimed: (1) that the Canadian ban violated Ethyl's right under NAFTA to "national treatment": because the ban prohibited only MMT's import and not its production or sale and thus treated Ethyl less favorably than Canadian enterprises; (2) that the ban functioned as a prohibited "performance requirement" under NAFTA because its effect would be to require that Ethyl Corporation either produce in Canada or use Canadian-

5.5 Even many free marketeers have been shocked by the brassy claims investors have devised in the context of NAFTA's Chapter 11. There are indications that even in the neoliberal camp, there is some pressure to moderate the tools that Chapter 11 has placed in the hands of international investors, tools that are giving such a bad name to investor rights. See Peter Menyasz, Reform of NAFTA Chapter 11 Will Be Top Priority for Canada, 18 INT'L TRADE REP. 626 (2001) (discussing Canada's push "for clarification of certain aspects of the investor-state-dispute provisions in [NAFTA's] Chapter 11"); NAFTA Members Taking Stock on Fifth Anniversary-Marchi Hopes for Some Action on Trade Irritants, TORONTO STAR, Apr. 19, 1999, at 1 (discussing Canadian International Trade Minister Sergio Marchi's desire to make NAFTA's Chapter 11 "more narrowly interpreted-as was the original intention"). One big question is whether negotiators of the Free Trade Area of the Americas will end up rethinking some of Chapter 11's provisions, which has been proposed as the basis for the FTAA regime as well. See Peter Menyasz, Regulatory Chill of NAFIA Chapter 11 to Be Avoided in FTAA, Lawyer Warms, 18 INT'L TRADE REP. 626 (Apr. 19, 2001) (discussing Ottawa trade lawyer Howard Mann's opinion that an FTAA agreement "should not adopt the investor-state dispute settlement provisions of [NAFTA] in their current form, because they would threaten prospects for hemispheric free trade"). See infra text accompanying notes 56-67 (discussing the Ethyl Corp. case).

56) $\mathrm{MMT}$ is a gasoline additive little used in the United states, but long used in Canada. The manganese-containing additive was targeted by environmental groups in the $1990 \mathrm{~s}$ as a potential threat to health, but Ethyl fought off attempts to ban the chemical. Ethyl is the only producer of MMT in the world. See Krista McKinsey, Run ning on MMT? The Debate on the Health Effects of a Gasoline Additive Rages On, SCI. AM., June 1998, at 35 (summarizing the debate on MMT and its health effects, and discussing Ethyl Corporation's lawsuit to legalize MMT in the United States and Canada).

${ }_{58}$ See Elhyl Corp. v. Canada, discussed in MANN, supra note 54, at 71-74.

58 "National treatment" requires that foreign investors be treated "the same as" (or at any rate, no worse than) domestic enterprise. 
made substitutes for MMT; ${ }^{59}$ and (3) that the ban was either an "expropriation" or was "tantamount to" expropriation because of the impact on Ethyl's business and its profits. ${ }^{60}$ After the case survived a jurisdictional objection by Canada, the latter decided to settle, reportedly in order to avoid an unfavorable decision in another forum. Canada paid Ethyl $\$ 13$ million, withdrew the legislation that Ethyl opposed, and gave the corporation a letter stating that there was a lack of scientific evidence to prove a health risk from MMT. ${ }^{61}$

In another case, the U.S.-based Metalclad Corporation sued the government of Mexico for sums the company spent in preparing a site for a hazardous waste landfill facility in the town of Guadalcalzar. ${ }^{62}$ Despite apparent federal approval of the project, local resistance was strong, and municipal authorities denied the company a construction permit. In addition, the state government eventually declared the site an ecological preserve. Metalclad claimed that various aspects of the treatment it received in Mexico violated the "minimum standards of treatment" required under NAFTA, and further, that the government's action was an "expropriation." "The Tribunal ruled against Mexico and awarded the Metalclad Corporation $\$ 16,685,000$. Mexico appealed to the Supreme Court of British Columbia, ${ }^{64}$ but succeeded only in knocking out a portion of the award. ${ }^{65}$ The court upheld the gravamen of the award, holding that the tribunal below had been

59 "Performance requirements" prohibited by NAFTA include certain anticipated rules that require foreign investors to perform a local service or deliver a local benefit in return for the right to invest within the jurisdiction.

${ }^{60}$ See Ethyl Corp. v. Canada, discussed in MANN, supra note 54, at 71-72. See also supra note 47 (discussing the rules about regulatory takings in the context of trade agreements).

${ }^{61}$ See Ethyl Corp. v. Canada, discussed in MANN, supra note 54, at 71-72. Note that a related dispute brought against the Canadian federal government by four provinces seeking relief from the MMT ban complicates the Methanex picture and may have been part of the motivation for the Canadian government's decision to settle the Chapter 11 case with the Ethyl Corporation. MANN, supra note 54, at 71-74; Gudofsky, supra note 47 , at 244-45 n.2.

${ }^{62}$ Metalclad Corp. v. United Mexican States, ICSID Case No. ARB(AF) $/ 97 / 1$ (Arbitral Trib., Aug. 30, 2000), available at http://www.worldbank.org/icsid/cases/mmaward/e.pdf. For a critical summary and discussion of this case, see MANN, supra note 54, at 74-79. For a favorable account of the case, see Gudofsky, supra note 47, at 263-64 \& n.56.

${ }^{63}$ Metalclad, ICSID Case No. ARB(AF)/97/1, Award II 1.

${ }^{64}$ The jurisdiction of the court in British Columbia was based on the fact that the underlying arbitration had been conducted in Vancouver. United Mexican States v. Metalclad Corp., 2001 B.C.S.C. 664, If 56 (B.C. 2001), available at http://www.worldbank.org/icsid/cases/metalclad_reasons_for_judgment.pdf.

${ }^{65}$ Id. \I 133-37. 
within the scope of its authority when it ruled that the state government's decree creating an ecological preserve amounted to an "expropriation" under Article 1110 of NAFTA's Chapter 11. The Supreme Court of British Columbia saw its role in reviewing the arbitration award as narrowly limited under the governing arbitration statute and observed:

The Tribunal gave an extremely broad definition of expropriation for the purposes of Article 1110. In addition to the more conventional notion of expropriation involving a taking of property, the Tribunal held that expropriation under the NAFTA includes covert or incidental interference with the use of property which has the effect of depriving the owner, in whole or in significant part, of the use or reasonably-to-beexpected economic benefit of property. This definition is sufficiently broad to include a legitimate rezoning of property by a municipality or other zoning authority. However, the definition of expropriation is a question of law with which this Court is not entitled to interfere under the International $C A A^{66}{ }^{66}$

In a third case, Methanex, a Canadian corporation, has sued the United States, complaining of a California order that would ban MTBE, a gasoline additive, in all automobile fuel sold in the state. ${ }^{67}$ Methanex claims that the California ban would unfairly penalize it and other MTBE producers for a problem that is actually the result of California's own failure to control air and water pollution caused by leakage from underground gas tanks and poor performance by small two-stroke motors. Methanex also raises another set of issues in recent amendments, claiming that its U.S. competitor, Archer Daniels Midland Company, made significant contributions to the California gubernatorial campaign of the winning candidate, not in violation of U.S. law, but in a way that produced what it claims is an actionable lack of fairness for Methanex in the MTBE matter. The company's legal theories under NAFTA's Chapter 11 are that California has failed to provide "national treatment," that it has not followed "minimum international standards of treatment," and that it has "expropriated" the company's investment. It seeks approximately one billion dollars in damages.

${ }^{66} I d .9199$. The International CCA is the commercial arbitration statute that the court deemed relevant for determining its scope of review.

${ }^{67}$ For a summary and discussion of Methanex Inc. $v$. United States, see MANN, supra note 54 , at $96-99$.

${ }^{68}$ This case is noteworthy not only because of the high damages being sought, but also because the Tribunal has agreed to accept amicus submissions from nongovernmental organizations (NGOs), though it will not allow them to participate in oral ar- 
The investor-state dispute-settlement provisions that opened the door to these extraordinary claims and others like them are presently restricted to NAFTA, but are unlikely to remain so. Similar rules were proposed for the now-stalled Multilateral Agreement on Investment (MAI) before that agreement got such bad press and provoked so many howls of protest that it was quietly put back on the shelf, at least for now. ${ }^{69}$ These kinds of provisions have also been proposed for the Free Trade Area of the Americas (FTAA), the expansive NAFTA-like pact now in the works that would extend to all countries in the Western hemisphere but Cuba. ${ }^{70}$ Intense controversy over Chapter 11 and its impact has led to some backpedaling by the United States and the other two NAFTA signatories, aimed in part at cooling debate about inclusion of the same or a similar regime in the FTAA. The effect of this tweaking, however, is not yet clear. ${ }^{71}$ Meanwhile, investor-state

gument. See MANN, supra note 54, at 96-99 (explaining that the Tribunal's acceptance of amicus submissions from NGO's is an important development in Chapter 11 cases).

${ }^{69}$ For varying perspectives on the MAI, see BUREAU OF ECONOMIC AND BUSINESS AFFAIRS, MUlTILATERAL AGREEMENT ON INVESTMENT (MAI): THE FACTS (1998), available at http://www.ustr.gov/agreements/index.html; TONY CLARKE \& MAUDE BARLOW, MAI: THE MULTILATERAL AGREEMENT ON INVESTMENT AND THE THREAT TO CANADIAN SOVEREIGNTY (1997); UNITED STATES COUNCIL FOR INTERNATIONAL BUSINESS, A GUIDE TO THE Multilateral AgreEment on InVEstment (MAI) (1996); and Tema de Tapa: Acuerdo Multilateral de Inversión: Las Grandes Empresas Gobernan el Mundo, 78 Revista del Sur 3 (1998) (published by the Third World Network, headquartered in Malaysia, with Latin American offices in Uruguay). See also Ansley, supra note 52, at 418-20 (describing the adverse reaction of social movements and parliamentarians to some of the MAI's provisions). For a draft text of the dormant MAI, see http://www.igc.org/ habitat/mai, a webpage maintained by the Ad Hoc Working Group on the Multilateral Agreement on Investment.

${ }^{70}$ For the current text of the FTAA, released after steady pressure and agitation by anti-free-trade groups, see the official FTAA website at http://www.ftaa-alca.org/. The FTAA is still under negotiation. Like the WTO, it has become the target of substantial protests, most recently in Quebec City in April 2001. It has also prompted the emergence of the Hemispheric Social Alliance, which has produced a series of alternative proposals and strong critiques of both the substance and process of FTAA negotiations to date. See Hemispheric Social Alliance, Alternatives for the AmEricas 43-79 (2001), available at http://www.asc-hsa.org/pdf.altering2/pdf (addressing the major topics on the official FTAA negotiation agenda, including investment, finance, intellectual property rights, agriculture, market access, services, and dispute resolution).

${ }^{71}$ In July 2001, the trade ministers of all three NAFTA countries signed off on a set of interpretations clarifying aspects of NAFTA's Chapter 11. Free Trade Commission Clarifications Related to NAFTA Chapter 11, at http://www.ustr.gov/regions/ whemisphere/nafta-chapterl1.html; see also Rossella Brevetti, NAFTA Trade Ministers Clarify Chapter 11 Investment Provision, 18 INT'L TRADE REP. 1234, 1234 (2001) (stating that NAFTA trade ministers agreed to clarify the General Treatment Clause, which states that investors should receive fair and equitable treatment from NAFTA signatories). The interpretations aim to clarify two main points. First, Chapter 11 is to be governed by "the customary legal standard as opposed to creating a new one as some 
mechanisms also have been mentioned for the agenda at the next round of negotiations in the World Trade Organization (WTO), although the future of that round has become somewhat less certain in the wake of the demonstrations in Seattle, Prague, and Genoa. ${ }^{72}$

In all of these contexts, existing or proposed one-sided investor protections and new international trade and investment regimes significantly restrict the power of governments to set national economic policy or to pursue national development strategies if those policies or strategies are at variance with neoliberal precepts. This new global legal order, a kind of "global constitutionalization" of international investment rights, ${ }^{73}$ has reinforced my embrace of the lessons and imagery $I$ have suggested in $P_{1}$ above. Polities do, indeed, need the power to hold economic actors accountable to those who do business within their boundaries.

litigants have argued." Id. Second, Chapter 11 procedures are available only for the obligations explicitly set out in the Chapter itself, and are accordingly not available to corporations who want to use it to enforce other NAFTA sections or other trade deals. See id. (dismissing an argument that has been raised in Chapter 11 cases that the clause creates obligations under other NAFTA provisions or other international agreements). NAFTA critics have charged that the new interpretation "completely ignores many of the most objectionable aspects of the Chapter 11 rules," especially "the broad definition of expropriation." Letter from Alliance for Responsible Trade et al., to Ambassador Robert B. Zoellick, United States Trade Representative, et al. 1 (Aug. 31, 2001) (on file with author).

${ }^{72}$ The WTO already erects a strong free trade rule structure, including prohibitions on practices it characterizes as "subsidies" (viewed as non-tariff barriers to trade). It has not yet, however, taken up NAFTA-like investment provisions. For more on the WTO, see ThE WORld Trade Organization: Trading into the Future: The INTRODUCTION TO THE WTO, available at http://www.wto.org/english/thewto_e/ whatis_e/tif_e/tif_e.htm, and information on websites of some of its critics, such as Fifty Years Is Enough, at http://www.50years.org; the International Institute for Sustainable Development, at http://www.iisd.org; and the Institute for Agricultural \& Trade Policy, at http://www.iatp.org.

${ }^{73}$ Critics and supporters alike have remarked on the constitution-like characteristics of today's regional and multilateral trade regimes. An oft-quoted example is from Renato Ruggiero, then director of the World Trade Organization, who characterized the multilateral trading system as "a 'constitution' for the world economy." Renato Ruggiero, The Multilateral Trading System at Fifty, Address to the Royal Institute of International Affairs in London, United Kingdom (Jan. 16, 1998), available at http://www.wto.org/english/news_e/sprr_e/london_e.htm. He went on to say, “The central governance challenge of our new global age is perhaps this: whereas governments answer mainly to national constituencies, increasingly the economic system must answer to global needs." Id. He did not address the question of who was to define these "global needs." Id. 
But the world as seen through a $P_{1}$ lens has also come to strike me as fraught with danger. I have come to feel uneasy about its implications in some respects, at least in the context of a social movement born and bred in the United States. The factor that most profoundly unsettled my equanimity about defending the bounds of home in a global age was my very local encounter with a very global phenomenon: mass labor migration.

\section{Plant Closings and Defense of Community: Human Mobility}

It is hard to describe all the ways that the plant-closing movement got mixed up with the question of immigration. It was a gradual process, at least from the vantage point of Tennessee. But whatever the multiple intersections between the plant-closing movement on the one hand and the new surge of low-wage Latino immigration on the other, the encounter between the two was destabilizing for frameworkers like me in many ways.

Rhetoricians who had been busy talking about the importance of boundaries for enabling democracy and empowering those on the receiving end of globalization were suddenly confronted with a quite different perspective on national boundaries. In the expanded context of immigration policy, strongly defended boundaries around the communities of the privileged center seemed to exacerbate rather than to balance power differentials that had begun to yawn so ominously between footloose transnational corporations and nationally grounded workers. Far from protecting the ability of directly affected workers and communities to help set economic ground rules for corporate behavior, strong boundaries in this new context seemed to reinforce privilege and exclude many voiceless people from relevant democratic deliberation. The encounter thus posed a serious challenge to my $P_{1}$ assumptions and my $P_{1}$ themes about the jurisdictional foundations for democracy.

My first glimpse of the immigration issue as something that was close to home came during a road trip to Mexico, when I was traveling with a group of factory women on a worker-to-worker exchange trip to the border. Our Tennessee delegation had met with women who worked at maquiladora plants in the towns of Matamoros and Reynosa, in the state of Tamaulipas, Mexico, and we had toured several communities where maquila workers and their families lived. What we saw then was profoundly disturbing in many ways that had already been 
the topic of animated discussion among our delegation. ${ }^{74}$ On this occasion, however, the talk turned to home, and the topic was something that had not been even remotely on my radar screen up to that time. Several women from a small town northeast of Knoxville were comparing notes on their impressions of the trip, and two of them began saying that the exchange had made them think about "all those Mexicans" they had begun to notice back home.

I was fascinated. What did they mean "all those Mexicans?" Soon they were telling stories about new developments in their communities. They told about isolated trailers tucked away at the edges of tomato fields out on unpaved country roads. They told about new groups of "different-looking" people playing basketball in the public park. They told about being asked to dance by Spanish-speaking strangers when they went out for a couple of beers on Saturday night. One interchange on that van ride went something like the following:

My sister drove back in there last summer, and she saw them picking tomatoes. She told me I had to go see it with my own eyes, but I still haven't gone out there. She told me those men were running with their buckets. Running down those rows, you know, where they have to empty their buckets into the truck. They were running. It is a crime to do people that way. And anyhow, what do you reckon they've got in mind for $u s$, if they are doing them that way?"

This trip makes me think about what those people are coming from when they decide to move here. You know what I mean?

What gets me is how people look over them in the grocery store. They just look over them. Over their heads. Like they're not even there. How would that make you feel?

This conversation got my attention. After the trip was over, I started looking more closely at what was happening demographically in East Tennessee; it soon became evident that the trend my friends had described was affecting many more communities than that one wide place in the road with its expansive tomato fields and its busy chicken-processing plant. Latino and Latina immigrants were showing up in rural and urban counties all over the state. Most of them were from Mexico, but many were from Central America as well. A high proportion of them were undocumented, many were living in families with "blended" immigration status, and they were present, by all accounts, in numbers the region had never seen before. ${ }^{75}$

\footnotetext{
${ }^{74}$ For more on the range of issues encountered on this and several similar trips, see Ansley, The Gulf of Mexico, supra note 22; Ansley \& Williams, supra note 22; and From the Mountains to the Maquiladoras, supra note 21.

${ }^{75}$ See, e.g., David Frey, Burgeoning Hispanic Population Challenge for Law Enforcement,
} 
These newcomers were finding their way into niche employment in the toughest and worst-paying jobs our regional economy has to offer-harvesting tomatoes, washing dishes, processing poultry, digging ditches, hanging dry wall, pruning nursery stock, removing asbestos, and the like. New day-labor agencies and temp services with Spanishspeaking staff began springing up to act as brokers between area businesses and this brand new kind of worker. Latinos could be found searching the men's clothing racks in thrift stores, dropping off kids at school, swelling the pews at Catholic and evangelical church services, seeking help in hospital emergency rooms, forming and playing in new soccer leagues, going to jail, dating the locals, sending money orders home on Friday afternoons by Western Union, and waiting in line at the Greyhound bus station. ${ }^{76}$ Eventually, we even got our very own INS office, and some immigrants found themselves detained and sent to Memphis for deportation."

Knoxville News-Sentinel, Mar. 9, 2000, at A6 (stating that the Hispanic population in Tennessee is growing rapidly and quoting a statistic that between 1998 and March 2000, the number of Hispanics in Tennessee increased by more than 100,000); Hannah Wolfson, 1990s Bring Boom in Tennessee's Hispanic Population, ChatTanooga Free PrEss, Nov. 23, 1998, at B3 (citing a finding by the U.S. Census Bureau that between 1970 and 1997 Tennessee's Hispanic population grew by seventy-three percent); Hannah Wolfson, State Heaven for Hispanics: Tennessee's Grotuth Is Sixth Best in Nation, MARYVILlE DAILY TIMES, Nov. 23, 1998, at A1 (stating that Hispanics are becoming part of the fabric in Tennessee and that Tennessee has one of the fastest growing rates of Hispanic population in the United States).

${ }^{76}$ For more impressions of these changes, see Fran Ansley, Putting the Pieces Together: Tennessee Women Find the Global Economy in Their Oun Backyards, in WOMEN WORKING. THE NAFTA FOOD CHAIN: WOMEN, FOOD \& GlobAl.IZATION (Deborah Barndt ed., 1999).

${ }^{77} \mathrm{I}$ am telescoping somewhat in this description. For a number of years, immigrants were seldom deported from East Tennessee unless they were already in custody for a serious criminal offense. There was no significant INS enforcement capacity in our end of the state. Sometimes there would be a story in the paper about, say, a "vanload of illegal aliens" that had broken down on the interstate. Usually such stories would report that the Highway Patrol had simply sent these folks on their way because the nearest INS office (in faraway Memphis) could not spare a van or driver to come way over here to pick them up. After such incidents, our local conservative congressman would typically deplore the situation and vow to get us some help for dealing with this problem. Eventually, his vows were fulfilled. Within a few years, Congress appropriated generous sums for the INS to open several new "rapid response" offices in Tennessee and other interior states that were going through similar demographic changes. See, e.g., INS Opens Office in Knoxville, Two Other State Cities, KNOXVLLE NEWSSENTINEL, May 15, 2000, at A1 (discussing congressional funding for the establishment of INS offices and teams in Knoxville, Chattanooga, and Nashville); Tennessee to Get Five Teams of Immigration Agents by Fall, KNOXVILLE NEWS-SENTINEL, Apr. 3, 1999; Monica Whitaker, Truckload of Immigrants Fails to Grab INS Attention, TENNESSEAN, Mar. 21, 1999, at Al (discussing the lack of resources in interior states for documenting and deporting undocumented workers). 
Local newspapers started running occasional stories about this new phenomenon. In such articles, employers of Latinos were often interviewed, and they were among the immigrants' most vocal fans. It was clear that some employers had begun to see what the term "work ethic" could really mean in the hands of, for instance, a young sojourning immigrant with little idea of his employment rights, even less inclination to demand them, and a strong desire to log the most work hours possible during his temporary, income-focused stay in the United States. $^{78}$

The reception these immigrants received from others in East Tennessee ranged from cordial and welcoming to overtly racist and xenophobic. On the welcoming side, a variegated range of churches saw the new population as an important source of new members, and soon got busy doing outreach and hiring Spanish-speaking clergy. Some cosmopolitan types were delighted to hear Spanish spoken on the street or to find exotic new dried peppers and herbs on the shelves at the local supermarket. Some teachers took the occasion to set up multicultural lesson plans. One community organization began hosting an annual "welcome back" party for migrant farmworkers in the spring.

But there were uglier responses as well, and several objective and subjective factors encouraged an attitude of competition in many native-born employees who encountered immigrants on the job or heard about their presence and their impact. For instance, the conditions under which immigrants were toiling and the fierce pace they tended to set in their work could, in fact, exert pressure on fellow workersusually in ways that immigrants themselves had little context for appreciating. The immigrants were often paid less, or if they nominally earned the same as native-born workers, they often worked harder and longer for what they got. ${ }^{79}$

${ }^{78}$ See, e.g., Robert Moore, Central Americans Are Finding Work, Homes in Hamblen County, Citizen-Trib. (Morristown, Tenn.), July 23, 1993, at A6 (describing Central Americans' acclimation to living and working in Hamblen County, Tenn).

${ }^{79}$ A recent article in a monthly bilingual newsletter covering East Tennessee sheds some light on these dynamics:

Where are the Hispanic people in this part of the country? ... What do they like? They like the nice people... . They like the fact that their hard-working spirit is appreciated by the business owners. They do not mind to be sometimes abused or deceived or misguided by those who they work for or those who they work with or even those they live by. Just like anybody else who has a definite goal in mind and heart: Success.

Carlos Nicho, Notes From the Editor, Mundo Hispano, Sept. 2001, at 3. 
Further, immigrants were often encouraged by employers and others to view native-born workers in these low-end jobs as slothful complainers. They were quickly tutored in American lingo for racialized designations of certain groups-including "white trash" as a signifier for low-income white workers and worse terms for African Americans.

In one rural community near mine, several hundred white people signed a petition and later marched to protest the planned opening of a Head Start center for migrant preschoolers. Farmworkers in this area stay in places widely scattered among the vegetable farms that employ them. In searching for a new site that would accommodate the numbers of children enrolled, the center had chosen a small community where no farmworkers lived, but which was equidistant from a number of settlements and camps where parents of its students were living. Residents of this community learned of the plans and mobilized to resist them. A leader of the protests observed that, " $[t]$ here are some good migrant workers who come here on a consistent basis, but there is just too much riff-raff that will bring trouble to the community." ${ }^{80}$

In the midst of the ensuing controversy, later in the summer of 1999, I attended a community meeting in the public park in Newport. The gathering was called by local people who supported the center to promote an "open dialogue" about the controversy. In the green shade of a lovely creek-side picnic area, surrounded by a bloom of festive balloons and crepe paper, with signs that said things like "Bienvenidos" and "Everybody Welcome," I sat with about a hundred other supporters and a few fairly calm opponents of the center. Clumps of other opponents, decidedly more nervous, stood around in the parking lot and cast darting glances over at the pavilion full of mothers, children, and visitors. Meanwhile, a couple of pickup trucks full of pumped-up younger men gunned their way down the access road, spraying gravel and generally letting off steam.

A small sound system had been set up, a couple of scruffy guys from a youth job-training program were capturing the proceedings on their own videotape, and a local TV camera was also rolling. After an initial welcome by center staff, a parade of amazing testimony was offered as people stepped up to the microphone and addressed the crowd. Comments ran the gamut. There was a church-goer who gave

${ }^{80}$ Timothy Graham, Migrant Center Hits Another Roadblock: Bybee Residents Opposing Facility in Their Community, NEWPORT PLAIN TALK, July 12, 1999, at 1 A . 
a heartfelt plea for Christian kindness toward the innocent children. A white kid with bad teeth, tattoos on both forearms, a lanky ponytail, and an attitude stepped out from behind his camera long enough to aim a declaration at opponents of the center: "All this crap you are pulling just to stop a place for kids. It's stupid. I mean pure stupid! That's all l've got to say." There was a soft-spoken narrative from a Latina staff member in a powder-blue blazer. She described what it had been like at age five to be the first Mexican child ever to attend school in nearby Erwin, Tennessee. There was a fiery challenge from an Ohio-born Chicana farmworker who asked the assemblage just who it was they thought was picking their tomatoes for forty cents a bucket and bringing them to their tables so red and tasty. She invited us native Tennesseeans to start picking our own.

At first it seemed as though the opponents might be too wary or disdainful to approach the microphone. Eventually, however, a number of them stepped up and voiced their opinions as well. Afterward, I wrote down all the reasons I could recall that various opponents of the migrant center had offered to justify their demand that it not be allowed to open. Here is the text of my notes from that evening:

\section{Reasons Given for Why a Migrant Head Start Center Should Not Be Opened in Bybee}

1. The proposed site is too wet and boggy for a septic system.

2. The proposed site has dangerous pesticide residues on the grounds from spraying by neighbors, so it poses a health risk to the children.

3. The proposed site is too far away from important services such as medical care and fire protection, so it poses a safety risk to the children.

4. A migrant Head Start center would decrease property values in Bybee.

5. There are no migrant workers and no Mexicans of any kind living in Bybee, so there is no need in Bybee for this service.

6. A day care center will become a magnet, a hang-out for Mexicans. There will be a seasonal increase in crime. We are likely to see rapes, stabbings, and murders happen in Bybee.

7. It would be better to locate child care centers on the farms where migrant workers are employed. The growers should provide housing for their workers and not just throw them off onto the community.

8. It would be better if the migrant workers were given $\$ 65$ per week and they could just hire babysitters who could keep the children in their homes.

9. The center is paid for with our federal taxes. It is unfair for our taxes to pay for services for them.

10 . We don't want these people here. Why don't you have them in your backyard? How would you like that? 
11. I went up North to find work a long time ago. And there were people there who didn't like hillbillies. They made that clear. They called us names. So I didn't want to live where I was not wanted. I came back home as soon as I could figure out a way to do it. And that is what these people should do. They should move on out of here.

12. Several years ago I worked in the packing shed down there at the farm, where they pack the tomatoes. And there were all kinds of Mexican men who worked there. It was those Mexican men who got me on drugs. They pushed them on me. They told me the drugs would make me feel good. They brought them in here from the border. And so I got onto drugs, and I got into trouble, and I spent time in prison. My life was a mess. And it was because of those Mexican men in there. It wasn't white men who did this to me, it was Mexican men. Is that what you want to see here in Bybee?

13. I fought in World War II, and I didn't fight for these people.

14. This program has always had a good location, right down there in that church building where they are. And there are fine schools right here in Newport that would have room. They should just stay in Newport where everything is better for them.

15. A day care center will cause increased traffic on the road up through there, and the road was not made to handle so much traffic. It will lead to accidents and injuries. There used to be a big Enka plant down there, and we had a lot of traffic back then, and there were more accidents then. ${ }^{81}$

Not long after the meeting, a barn on the property of the landowner who had agreed to lease a piece of land to the Head Start center was burned to the ground. A "crude effigy with a ketchup-stained T-shirt [was left behind] on the road across from where the proposed building will be."

There are many things that could be said about Bybee, about the

${ }^{81}$ I suppose it goes without saying that this is my nontransparent rendition of people's statements. You should read it critically in two directions. First, my attitudes toward this particular kind of social movement are far from neutral, so I may be spinning my report in ways designed for subtle combat. Second, I would like to avoid triggering among readers any of the stereotypes that can be so quickly conjured when lowincome white Southerners are represented in a racially charged narrative. Those stereotypes do a kind of cultural violence to their targets, but they also make it harder for the person temporarily occupied with the stereotype to avoid self-congratulation, a sentiment usually not very helpful in this context. You can probably see me struggling with it myself in these pages, and probably not always successfully.

${ }^{82}$ Randy Kenner, FBI Will Investigate Arson at Proposed Head Start Facility, KNOXVILLE NEws-SEnTINEL, July 27, 1999, at A4; see also Gary Butler, Bybee Bam Burns, NEwPORT PLAIN TALK, July 24, 1999. The controversy was reported nationally in the Spanishlanguage press. E.g., Marcela Mendoza, Residentes de Bybee, East Tennessee, Protestan Contra la Creación de un Day Care para Niños de Trabajadores Rurales Hispanos [Residents of Bybee, East Tennessee Protest the Creation of a Day Care Center for the Children of Rural Hispanic Workers], PrisnSa LATINA, Aug. 3, 1999, at 18. 
emergence of the anti-Head Start campaign there, and about that campaign's local participants and its local detractors. But one factor seems particularly salient for the larger difficulty discussed in this Article. Bybee is located in an area that has experienced significant job loss in recent years. In decades past, many small towns and rural areas in East Tennessee gained jobs as investors moved plants from the industrialized and unionized North as a way to find lower wages and a more business-friendly climate. But by the 1980s and 1990s, the tide began to pull in the opposite direction, with more and more jobs flowing to the global South, often headed for maquiladora factories in Mexico.

In communities like these, ill-informed but powerful resentments aimed specifically at Mexicans sometimes ran high. The trope that Mexicans were "stealing American jobs" was commonplace among some blue-collar workers, and it offered a frame that conflated both capital flight and immigration into one convenient and loaded piece of moral shorthand. Whether the jobs were stolen way down there in Mexico by maquila workers or right up here in Tennessee by immigrant laborers, this frame pictured both the process and the outcome as fundamentally the same, and fundamentally the fault of Mexican thievery.

The most common "pro-immigrant" response to this charge of job theft by Mexicans was to argue that at least north of the border in the United States, immigrants were only taking "the jobs Americans don't want." This response is often the first frame that friends of immigrants jump to in debates about the pros and cons of immigration, but I view it as highly problematic. It treats wages and working conditions as somehow essential, inherent, and unchanging features of the jobs themselves, rather than factors that are malleable and under human control. $^{83}$ More U.S. workers would be eager to do many of the jobs immigrants do if the wages and working conditions were more reasonable.

This theme of "unwanted jobs" implies there should be nothing

${ }^{83}$ To the contrary, wages and working conditions are products of complex social dynamics that vary over time and place. Ruth Milkman argues, for instance, that successful management attacks on unionization preceded demographic changes in many industrial sectors in California. Ruth Milkman, Introduction to ORGANIZING IMMIGRANTS: THE CHALlENGE FOR UNIONS IN CONTEMPORARY CALIFORNIA 1, 11 (Ruth Milkman ed., 2000) ("In many of the state's industries and occupations ... as wages and working conditions deteriorated after employers successfully eliminated or weakened unions, native workers simply exited and were subsequently replaced by immigrants."). 
troubling about building a labor market on a sub-group of foreign workers with limited legal rights and no political clout-in fact, it suggests it would make for a happy fit, as long as those workers are slotted of their own "free" will. According to this view, it matters not that immigrants' work is more distasteful, dangerous, and poorly paid than the sort of work the rest of the workforce, clothed with the rights and privileges of legal membership, presently prefers or is compelled to undertake. ${ }^{84}$ Such a vision implies a segmentation of the labor market that is highly correlated to race and is constructed and policed by immigration law. Further, it suggests that such a market should not only be tolerated by Americans, but welcomed by them. It invites American workers in particular to embrace color-coded and nationcoded labor market segmentation as appropriate and mutually advantageous to different groups of laborers, rather than to reject it as discriminatory toward individual immigrants and destructive of the possibilities for cross-race movement-building and solidarity. ${ }^{85}$ Some U.S. labor unions and U.S. social movements have begun searching for an alternative frame-one capable of resonating with both immigrant and native-born workers. Although important and energetic work is happening in labor- and community-based projects all around the country, the search for such a frame has not been easy.

At any rate, from my own vantage point in Tennessee, these ideological and material developments in nearby rural communities, this dizzying time-lapse display of racial formation in process, continued at a rapid pace. Immigrants continued to filter into the lowest job niches, and it really did appear that a new category was emerging: an entire stratum of racially marked and culturally distinctive long-term workers whose legal rights on the job and in the community were significantly fewer and weaker than those of "normal" employees."

${ }^{84}$ See Steven Greenhouse, Hispanic Workers Die at Higher Rate: More Likely Than Others to Do the Dangerous, Low-End Jobs, N.Y. TIMES, July 16, 2001, at A11 (noting, as to the danger invoked in manual labor, that "[j] ob safety officials say that Hispanic immigrants, often unskilled and often here illegally, are hired disproportionately into many of the most dangerous jobs, like roofing, fruit picking and taxi driving").

${ }^{85}$ Given the long, sorry history of our nation's use of the Mexican labor force as a safety valve and shock absorber for our own benefit and not theirs, such a vision of "complementary" segmentation seems especially suspect. Kevin Johnson has described the position of Mexican workers inside the NAFTA/INS system as "[l]abor exploitation based on treatment as outsiders within the regional market." Kevin Johnson, Regional Integration in North America and Europe: Lessons About Civil Rights and Equal Citizenship, 9 U. MIAMI INT'L \& COMP. L. REV. 33, 44 (2000-01).

${ }_{86}$ I should also note that low-wage immigrant workers often know little or nothing about those rights they do have, and such rights are seldom formally vindicated in 
These were people who lived in the community but were not viewed as a full or legitimate part of it. Their heightened vulnerability under immigration law made them correspondingly vulnerable to public and private abuse by everyone from employers, police, used-car salesmen, and landlords, to angry lovers, racist strangers, or opportunistic notarios peddling supposed help with immigration petitions. Meanwhile, it seemed clear to many of us that the emergence of a long-term and legally precarious underclass could not help but erode evenhanded respect for civil rights and civil liberties in general, thereby posing its own, more general kind of threat to strong democracy.

For native-born observers, these changes have been pretty amazing to behold. ${ }^{87}$ For those of us who were active in the plant-closing movement here, the wave of marginalized newcomers and the responses they encountered have raised troubling questions about our existing rhetorical practice. I had been mining the vein I have represented above as $P_{1}$, weaving images and heartfelt metaphors about the way democracy requires the maintenance of strong borders and the robust protection of local and rooted domestic economies by local and rooted democratic polities. Those usages began to look problematic to me in light of new immigration. I started to seek out immigrants, and when I asked some of them to share their stories, I was rewarded by a river of unsettling narratives about the crossing and policing of boundaries, about nativist defenses of an existing or imagined "home" against culturally or racially different newcomers, and

Tennessee, in part because so few lawyers in the state speak Spanish or have even a nodding acquaintance with the ways that immigration status can affect other legal rights and responsibilities of immigrants. My own law school has yet to offer a single immigration law course, and the state has no legal services program that is free of congressional restrictions on representation of undocumented persons and is in a position to offer bread-and-butter legal help to immigrants without papers, even if the language and skill barriers could be overcome.

${ }^{87}$ The beholding happened in various ways, both first-hand and second-hand. Broadcast media in our area began to process and respond to these developments. For instance, some local radio stations in the state began doing regular Spanish-language programming, while others aired anti-immigrant advertisements funded by out-of-state organizations, and others provided fora for anti-immigrant diatribes by right-wing talkshow hosts. Local print media ran varied stories about all these developments, but seldom asked probing questions or went much beyond the obvious. See, e.g., Ron Clayton, Residents Laud Aliens' Roundup, KNOXVILLE NEWS-SENTINEL, June 24, 1995, at A3 (discussing examples of Hispanic immigrants who want to live and work in the United States despite anti-immigrant sentiment); Immigrant Workers Part of Changing Landscape in City, Chattanooga Free Press, Oct. 13, 1995 (discussing the influx of immigrants in towns across the United States using the example of one man who moved from Guatemala to Chattanooga); Moore, supra note 78; 'Que Buena Onda! "What Good People" from Area Hispanic Community, CITIZEN-TRIB. (Morristown, Tenn.), July 6, 1997, at C1. 
especially about the life-threatening and long-contested border that runs along the U.S.-Mexico boundary, right through the heart of NAFTA country-that complex economic entity on whose turf I had been arguing most vociferously as to the need for bounded polities.

Of course, immigration flows were not restricted to Tennessee. Plant-closing activists and organizations all over the country had other versions of the immigration story happening in their home communities as well. Some of these groups found ways to cooperate with immigrants' rights organizations in the course of working on plant-closings and other economic justice fights. In fact, in some cases, battles for immigrants' welfare directly overlapped with fights against plantclosings because in some parts of the country the workers who were most affected by plant-closings were themselves immigrants. ${ }^{89}$

But more divisive dynamics were also in play. For instance, when the presidential campaign of 1992 heated up, Ross Perot managed to put NAFTA firmly on the nation's political agenda despite the efforts of the candidates of both major parties to let the issue of free trade remain dormant. Perot's frame for free trade and globalization was stridently and unquestioningly jingoistic, and many of the constituents that warmed to his rhetoric were also vocal critics of what they viewed as the nation's far-too-permissive immigration policy, with its clear threat to their vision of existing American culture.

Meanwhile, many of the energies and actors from the plantclosing movement began to join the anti-NAFTA campaign. As the

${ }^{88}$ On the historically contested nature of the boundary and its consequences, see Guadalupe T. Luna, On the Complexities of Race: The Treaty of Guadalupe Hidalgo and Dred Scott v. Sandford, 53 U. MiAmi L. REv. 575, 691 (1999). I was also interested to hear stories from immigrants about Mexican plant-closings. Contrary to the image most of us had that plant-closings happened only to workers in the global North, at least some of the workers who came to Tennessee had stories to tell about the closing of traditional workplaces in response to economic restructuring in Mexico. The casualties they described ranged from small farms and businesses unable to compete with large foreign-owned transplants, to previously state-run enterprises that shed tens of thousands of workers in the wake of privatization.

${ }^{89}$ See, e.g., Evelyn Iritani, Latino Immigrants Pay a Price for Free Trade Work, L.A. TimES, June 12, 2001, at Al (illustrating that the victims of NAFTA in America today are more likely to be Mexican immigrants, who are losing jobs to their brethren in Mexico, as U.S. companies open plants south of the border); Bill Medaille \& Andrew Wheat, Faded Denim: The NAFTA Numbers Crunch in El Paso, TeX. OBSERVER, Jan. 16, 1998, at 10 (discussing 6,472 laid-off workers in El Paso who had been officially certified as NAFTA casualties and predicting that after the 1997 casualties were processed, El Paso's NAFTA job-loss count would reach 10,000); see also Xavier Carlos Vasquez, The North American Free Trade Agreement and Environmental Racism, 34 HARV. INT'L L.J. 357 (1993) (exploring the environmental concerns raised by expanded economic trade between the United States and Mexico under NAFTA). 
fight against fast-track authority (and later against NAFTA itself) picked up political steam, and as crucial congressional votes drew near, many of these actors found themselves sorely tempted to build alliances with Perot forces in hopes of mustering enough votes to actually defeat the push for congressional approval. The attraction of these alliances caused some activists to view immigrants' rights as a divisive issue best left alone for fear of disturbing the emerging antiNAFTA coalition.

Of course unlikely, even unsavory, coalitions are hardly unusual in congressional politics. Tactical compromise is sometimes necessary and good. But in my view these particular alliances and the particular silences that they engendered were clearly bad ones for a social movement that was committed to egalitarianism and to getting a handle on the meaning of globalization. The dangers should have been more strenuously and consistently exposed and avoided than they were. The strategies and talking points developed with Perot forces in mind tended to distance the anti-NAFTA movement from important potential allies in domestic communities of color and in countries of the global South.

These developments were an indication, I believe, that we frameworkers of the plant-closing movement should have paid sharper attention to the exclusionary potential of the "bounded polities" and "local roots" imagery of the frame we were laboring to construct. Our frame at times cast a falsely simple and rosy light on the democratic practices of the American past, both in the electoral arena and within the American labor movement. On occasion we failed to give sufficient attention to the problem of who had been historically-and who was still presently-left out of the American polity or the house of labor and why. Questions about historical inclusion and exclusion seem especially salient given the geopolitical power relations, the particular channels of commerce and communication, and the material maldistributions that characterize today's global economy. All of these patterns and relationships bear the clear and present imprint of the colonial past, and suggest that America has never existed as something apart from a thoroughly international context.

In retrospect, it seems to me that we too often and too uncritically invoked a kind of golden age of past American democracy in order to rally people to democracy's contemporary defense. Of course, myths of golden ages are hardly unusual in the framingwork of social movements, and they have often shown their power to motivate and inspire collective action. I am not calling here on all honest frameworkers to 
renounce reliance upon past tradition as though the practice were some kind of vice to be foresworn. Nor am I saying that the problem with our rhetoric in the plant-closing movement was its factual inaccuracy about America's past-though certainly my own invocations of the New Deal as a standard to guide future judgment about democratic practice left too many troubling facts unmentioned.

To the contrary, movement frameworkers have a right and obligation to excavate, claim and celebrate the egalitarian and participatory strands of the American tradition, no less so because they also have a right and obligation to name and criticize other more exclusionary and oppressive strands of our inheritance. After all, no historiography, whether that of social movement rhetoricians or scholarly researchers, proceeds through unmediated transmission of unmediated facts. Historians will always be making hard and ambiguous choices and will always be building narratives whose shape is importantly determined by their own values, purposes, and strategies, and by the context in which they find themselves.

My point here is precisely about values, purposes, strategies, and contexts. In the plant-closing movement, our context included a home country that was founded on settler colonialism, was built in important part by imported enslaved workers, and is today the dominant economic and military power-the global economic leader-in a poverty-laden world where the economies of most poor nations are dependent upon, and subservient to, the economies of the rich ones. These features of our context were present all along, but I believe the encounter with immigration was an experience that brought them into much clearer and more troubling focus.

Given the context I have described, and given the movement's aspirations toward egalitarianism and economic justice, it seems to me that we in the plant-closing movement should have been more careful about how we invoked defenses of home. We neglected to include as strongly and vividly as we should have a more critical, inclusive, and internationalist edge to our nostalgic talk of a threatened polity and its righteous powers.

In fairness to the early anti-NAFTA movement, I should point out that we did not proceed in an entirely thoughtless way with regard to these issues. The various strands of the movement included enough participants from emerging immigrants' rights networks, and from progressive anti-NAFTA groups in Mexico, that critical voices beyond those normally included in domestic U.S. debates were heard and at least partly heeded. In the bitter aftermath of NAFTA's passage, some 
serious soul-searching did take place within the anti-free-trade movement, most notably about our frequent failure to speak out strongly and visibly on immigration policy and immigrants' rights during our work on the NAFTA campaign and to talk more about how free trade regimes looked from a third world perspective..$^{90}$

In the years following NAFTA's passage, as immigrants' rights organizations began to assert themselves more vocally at both the local and national level, and as they began to educate more native-born activists about the experiences of new immigrants and the issues important to them, more community-based and social movement organizations began to take immigrants' rights more seriously. The newcomers were themselves battering away at the existing frames through which many American activists viewed the world. Their "foreign" stories and global travels helped to widen our perspectives and shed harsh light on boundaries and traditions that we had too seldom sharply questioned in the past. ${ }^{9 !}$

In 1999, the AFL-CIO itself announced a true watershed change its own policy position on immigration, calling for the repeal of employer sanctions and a new amnesty for a broad group of undocumented workers in the United States. This heartening move both re-

${ }^{90}$ One venue where such soul-searching took place was at a conference, "Beyond NAFTA: Toward Equity and Sustainability," convened at the A.E. Havens Center for the Study of Social Structure and Social Change at the University of Wisconsin, October 6-11,1994. One of the major resolutions passed by the conference was a statement about immigrants' rights. Its passage followed a spirited discussion about the absence of such a policy statement during most of the grassroots campaigning against NAFTA.

${ }^{91}$ Scholars in many different fields, especially scholars of color, were meanwhile breaking new ground and exploring new perspectives on the colonial roots of the nation and the ways that America's ever-moving boundaries and ever-changing immigration policies have shaped the country and defined and ranked its members. In legal academia, for instance, LatCrit scholarship began to elucidate these themes in ways that have caused major rethinking about the American legal canon and about the national story. For a few entry points into this important literature, see Francisco Valdes, Foreword: Under Construction-LatCrit Consciousness, Community, and Theory, 85 CAL. L. REV. 1087 (1997); and THE LATINO/A CONDITION: A CRITICAL READER (Richard Delgado \& Jean Stefancic eds., 1998). See also Linda Bosniak, Exclusion and Membership: The Dual Identity of the Undocumented Worker Under United States Law, 1988 W1S. L. REV. 955, 968-76 (arguing that constitutional and statutory law have granted limited rights of membership in the national community to the undocumented immigrant but have concurrently curtailed these rights under the nation's border/protective powers); Ibrahim J. Gassama, Transnational Critical Race Scholarship: Transcending Ethnic and National Chauvinism in the Era of Globalization, 5 MICH. J. RACE \& L. 133, 137 (1999) (discussing the absence of a transnational or global perspective in the unfolding of "domestic" struggles for justice). For work of my own that is deeply indebted to the new perspectives opened by this work, see Fran Ansley, Recognizing Race in the American Legal Canon, in LEGAL GANONS 238 (J.M. Balkin \& Sanford Levinson eds., 2000). 
flected and strengthened other changes in the international politics of the national labor federation, and represented an important and tangible reorientation of labor's official approach to international worker solidarity. Especially in light of the exclusionary history embedded in many segments of the labor movement, the significance of this change can hardly be overstated. ${ }^{92}$

For my own part, a number of experiences caused me to begin reexamining the store of images and metaphors I had been drawing from, especially when I was framing outreach materials for U.S. workers. I listened to the persuasive arguments advanced by Mexican collaborators and immigrants' rights activists, especially their warnings about the anti-immigrant rhetoric that seemed to be breeding in many of the same venues where resistance to plant closings was strong. I observed how swiftly hyper-nationalist exclusionary frameworks could be triggered by calls for defense of homeland. I traveled to Mexico and saw how thoroughly integrated the U.S. and Mexican labor markets already were. I began to understand the political opportunities that were presented by new international fora and new international concerns and institutions. ${ }^{93}$ Additionally, I pondered an

92 The AFL-CIO had supported the creation of employer sanctions in the Immigration Reform and Control Act of 1986. The idea that U.S. workers would benefit from exclusionary immigration laws was deeply rooted in labor's history, although politics of immigration within the labor movement varied greatly across time, region, and industry. See generally GWENDOLYN MINK, OLD LABOR AND NEW IMMIGRANTS IN AMERICAN POLITICAL DEVElopMENT: UNION, PARTY, AND STATE, 1875-1920 (1986) (examining immigration, unionization, and labor politics in the late nineteenth and early twentieth centuries); ELMER ClARENCE SANDMEYER, THE ANTI-CHINESE MOVEMENT IN CALIFORNIA (2d ed. 1991) (discussing the restriction and exclusion of Chinese immigrants in the nineteenth century). On the change in immigration policy, see Defending the Rights of Immigrant Workers and the Right to Organize, AFL-CIO: 23rd Biennial Convention-Resolutions Book Two, No. 17, at http://www.aflcio.org (last visited Oct. 25, 2001). For a more general picture of the AFL-CIO's stance since moving away from its sorry CIA-linked Cold War practice, see John J. Sweeney, The Struggle for a New Internationalism, GEO. J. INT'L AFF., Winter/Spring 2001, at 5. See also ORCANIZING. IMMIGRANTS, supra note 83, at 51 ("[T] he AFL-CIO is one of the few mainstream organizations to have emerged as decidedly pro-immigrant, a stance marked not just by rhetoric but by action.").

${ }^{93}$ Whether and how new transnational arenas will provide space for fruitful crossnational collaborations are questions beyond the scope of this Article. Still, I feel safe in saying that the new trade regimes do create contexts where at least some horizontal, cross-border work can go on. For instance, labor rights advocates and organizers in the United States and Mexico joined forces to lodge a complaint in 1998 against the entire apple industry of Washington State under the NAFTA labor side agreements. Recently, under the auspices of the U.S. National Administrative Office, which was created by that agreement, officials held a "forum" on the question of whether the Washington apple industry is in compliance with U.S. domestic law on the treatment of ap- 
accumulating store of hard stories from newly arrived immigrants in Tennessee.

The learning curve associated with this kaleidescope of experiences was steep, and it caused me to look again and somewhat askance at my earlier formulation of $\mathbf{P}_{1}$ :

\section{The Dilemma, First Pole $\left(P_{1}\right)$}

Social movements interested in strong democracy must assert and defend the holding power of political boundaries, because in a globalizing world, the erosion of a polity's jurisdictional bounds renders democratic social disciplines toothless, increases inequality, and fortifies economic privilege.

The lessons triggered by my encounters with immigration suggested a second sort of distillation, a different set of rhetorical resources for framing a progressive social movement response to globalization. A boiled-down statement of the counterposed second pole that I was beginning to discern might be captured in something like the following:

\section{The Dilemma, Second Pole $\left(\mathbf{P}_{2}\right)$}

Pro-democracy social movements located in wealthy countries must insist on the openness and contingency of their boundaries, and must understand how their own polity relates to others, because in a radically unequal globalizing world, the fortification of a wealthy community's membership bounds renders democratic practices inauthentic, increases inequality, and fortifies economic privilege.

I do not mean to suggest that $\mathrm{P}_{2}$ should "supercede" $\mathrm{P}_{1}$. To collapse the lessons and wellsprings of $P_{1}$ into the world of $P_{2}$ would be to risk falling into an attitude that smacks of charity, an outcome that is neither morally attractive nor capable of powerful mobilization for change. The better goal for U.S.-based social movements looking to become more globally conscious would be solidarity. The trick, how-

ple workers. David Lester, Forum Looks at Farm Workers' Complaints, YAKIMA HERALDREPUBLIC, Aug. 9, 2001. The procedures for handling these kinds of complaints are lengthy and essentially toothless; not a single complaint has yet made it beyond the stage of ministerial consultations, and only a limited number of issues are deemed eligible to do so. Therefore, some activists have questioned the procedures' value. On the other hand, these emerging transnational institutions and procedures have provided occasions and structures for U.S. workers and unions to collaborate with counterparts in the other signatory countries and to begin to learn about their issues and perspectives. 
ever, is building a kind of solidarity that is properly cognizant of power differentials and appropriately wary of false universals. In my own work I now see the challenge as how I can draw at one and the same time upon the orientations and resources suggested by both $P_{1}$ and $P_{2}$.

\section{SOCIAL MOVEMENTS AND GLOBALIZATION: BUILDING RE-IMAGINED COMMUNITIES FROM BELOW}

Whether social movements in the global North and the frameworkers involved in those movements will manage to operate productively in the force field between the horns of the foregoing dilemma is an open question. Certainly such an undertaking is no easy matter.

I am particularly aware that some will see it as hopeless utopianism to think that a large segment of the U.S. populace could be convinced to embrace the open-borders undercurrent and the critique of U.S. dominance that are both implied in the way I have framed $P_{2}$. It is hard enough for most people on the receiving end of globalization to believe that they can successfully stick up for themselves and for those they perceive as their own kind. It is an even taller order if such people are asked at the same time to look beyond their existing circle so as to take account of, and make common cause with, physically or culturally distant others across various lines of race and nation.

Inviting large numbers of U.S. workers to view the world through a frame that highlights our nation's startling power, its wildly disproportionate consumption of the world's resources, and its steady downpour of impacts on poor people living in weaker and poorer states will not be an easy sell for U.S.-based social movement frameworkers. It is a huge challenge to draw people to a frame that asks them to contemplate their own lopsided privilege as compared to the situation facing many other inhabitants of the world system, or that asks them to be critical of their own country's lopsided power as compared to that of other nations.

After all, who wants to be lectured about her unearned gains or to be asked to take on new ties of reciprocity beyond her familiar and already challenging circle? Is it realistic to think a social movement can motivate substantial numbers of people to seek the undoing of structures that provide them with at least some short-term privileges? Who among the disadvantaged wants to complicate past successful deployments of patriotism when that strategy has in the past proved an important road to first-class citizenship for people previously excluded, and has served as a bulwark against some kinds of isolation? Who 
wants to be told that she should rethink deep and stirring loyalties that were passed down to her by beloved and respected elders?

My call to a privilege-conscious frame for northern social movements may thus sound quixotic on two counts. Many social movement theorists would likely question the viability of a project that seems to stray so far from an understanding that rational self-interest and material incentives are key to the growth and trajectory of social movements. Framing processes may have power, such theorists might say, but not that kind of power. Those social movement theorists who are more struck by the power of ideology would likely question the viability of my project in converse fashion. After all, my suggestion would ask Americans to let go of a hyper-nationalist frame that is deeply rooted in this country. It would ask them to take up the uncomfortable task of seeing themselves as one constituent part of a larger international community of potential equals, one in which American dominance is not always an object of gratitude and celebration, but is instead-and perhaps more often than we might want to contemplate-a target of impatient and indignant protest. Such a goal, they might well argue, requires a Herculean, perhaps impossible, shift of frame.

These hypothesized critiques of my project have bite. I do not dispute for a minute that the task of building successful internationalist frames will be extremely difficult for U.S. social movements to accomplish, for reasons of both ideological heritage and perceived selfinterest. Many previous failures to build and advance such frames have been at least as attributable to the chilly or hostile responses from crucial audiences as to the absence of internationalist vision or desire on the part of movement frameworkers.

My only defense to these objections is that, at least for currently disempowered communities, there is no alternative. Unless poor and working-class people in the world's North achieve the capacity to see themselves in a global context, it will be flatly impossible for them to build organizations that are strong enough to defend their interests or to carry out successful campaigns for economic justice. This "long view," however, is a far cry from most Americans' understanding of themselves or of their country and its place in the world. ${ }^{94}$

For all of the difficulties attendant upon constructing a social

One book that is full of information that could help U.S. social movements gain more perspective on some of the difficult questions raised in this Article is DANA FrANK, BuY AMERICAN: The UNTOLd StORY OF ECONOMIC NATIONALiSM (1999), which looks at the history of purportedly patriotic purchasing in the United States. 
movement frame that convinces wide audiences in the North of the importance of the internationalist perspective embedded in $P_{2}$, it is not much easier to convince wide audiences in the North that political deliberations should govern markets, as prescribed by $\mathrm{P}_{1}$. To the extent that $P_{1}$ represents a call for imposing transparent and participatory political disciplines on economic ground rules, it comes up against the juggernaut of neoliberal ideology. The current neoliberal deification of a falsely naturalized "market" has achieved astonishing sway in policy circles and in the media-conditioned public discourse of the global North, and it has either converted or coerced much of the local business elite and domestic political leadership in the global South.

At least in public, neoliberal ideologues have not attempted to jettison nationalist sentiments, so much as they have focused on harnessing them to the goal of freedom for transnational corporate enterprise, usually in the name of national competitiveness. Their strategy has so far met with mixed results. Large numbers of blue collar, lowwage, and no-wage workers in the United States and elsewhere remain stubbornly unconvinced. The post-Seattle emergence of global networks bent on protesting corporate-led globalization is certainly a noteworthy development that will no doubt attract much attention from organizers, social movement scholars, chiefs of police, and heads of state. However, professional and academic types have on the whole been much more open to persuasion to the banner of free trade, sometimes casting champions of $\mathrm{P}_{1}$ thinking as retrograde losers who have simply failed to get with the new, exciting, cosmopolitan program.

I do not pretend to have an answer for the difficulty of persuasively joining the two stylized perspectives I have set out above. I do, however, have one concrete proposal for how social movement constituencies in the wealthy countries might begin to understand more about their place in the global economy, and how social movement frameworkers might take part in gaining and sharing this understanding. Progressive social movements in the North should immerse themselves in deeper and more regular dialogue with corresponding individuals and groups in the rest of the world.

I am not merely calling for strategic coordination of campaigns or for contacts between high-level staff members or officers, although both of these are certainly good ideas. The gravamen of my proposal is that social movement organizations and "social movement entrepreneurs," to use a phrase from the literature, must devote substantial 
time and resources to enabling and supporting horizontal, person-toperson interaction between ordinary members of their movements and people who are in other physical or social locations in the global economy. Such interactions, I believe, will be important educational and trust-building experiences in their own right; moreover, they will function as an important incubator for the new images, metaphors, and shared understandings that rhetoricians are going to need if they want to help construct more inclusive and more globally conscious frames that resonate with larger publics.

Whether or not such conversations and associated collaborations will ripen any time soon into true "global social movements" is not my concern at this point. Rather, I propose this collaboration and communication as an urgent educational endeavor and as a way that social movements in the global North can find the materials and perspectives needed to construct and project frames that are sufficiently persuasive to advance the fight for a just and sustainable global future.

My conviction in this matter is probably fed in part by experiences at the Highlander Research and Education Center, ${ }^{95}$ where I have been able to observe that institution's concept of peer education in action. This long-time center devoted to adult education for social change runs residential workshops for emerging leaders, typically from low-income communities around the U.S. South, but sometimes from other regions of the country or the world.

Time and again, the grassroots people who attend Highlander workshops-whether from rural Appalachia, inner cities, Indian reservations, third-world countries, or elsewhere-turn out to be their own best teachers. Through talking with others in an informal, nonhierarchical, and face-to-face setting, and through a process of identifying similar problems among group members and trading stories about attempts to address them, participants come to better recognize and appreciate their own knowledge. The interchange also seems to help participants appropriate and mobilize lessons from others' experiences. In its early years, during the 1930 s and 1940s, Highlander often brought together working people from the U.S. South across racial lines. At the time, this practice defied both custom and law in the region, so the emotional and cultural distances that participants were

${ }^{95}$ For more information on Highlander, see FRANK ADAMS, UNEARTHING SEEDS OF Fire: The IdeA OF Highlander (1975); JoHn M. Glen, Highlander: No ORdinary SCHOOL (2d ed. 1996); Myles HORTON, THE LONG HAUl: AN AUTOBIOGRAPIYY (1990); Bob Edwards \& John D. McCarthy, Social Movement Schools, 7 SoC. F. 541 (1992); and YOU COT TO MOVE (First Run/Icarus Films 1985). 
asked to travel were significant.

In my view, today's global economy has created an urgent need for a new kind of peer learning across difference and distance. Progressive social movements, especially if they focus on questions of economic justice, should actively seek ways to promote and enable "peer global learning," through horizontal exchange between and among different subordinated communities around the world. ${ }^{96}$ Distance, language, race, nationality, and religion will all present sizable obstacles to convening such conversations or to following up on them once they are commenced, whether the conversations happen face-toface or through one of the new long-distance connections that are now becoming possible. In either case, the difficulties only make the conversations more, not less, important.

One specific arena in which I can envision a salutary role for horizontal global storytelling is in bridging $P_{1}$ and $P_{2}$ members of differently-situated polities around the world who have experiences with both these poles, and could learn a great deal by hearing from each other. There are many grassroots and rank-and-file activists from the United States who have been fighting in the world of $P_{1}$. These groups have been working to hold corporations accountable in their own jurisdictions, to assert the power of democratic politics to make enforceable rules of corporate behavior, and to insist on the right and duty of government officials to develop and pursue economic policies reflecting input from their human constituents. These activists need many more opportunities to hear from their counterparts in poor countries who have been fighting for the "same thing," but who encounter a set of obstacles unknown to most people in the United States even though our own government and corporations headquartered in our own country are heavily responsible for erecting and promoting those obstacles and insulating them from democratic revision. I predict that what begins as an exchange about similarity will almost inevitably move to include a discussion of difference-of

96 For examples of exchanges between and among subordinated communities in the context of globalization, see Highlander Res. AND Educ. CTR., ENvironment AND DEVELOPMENT IN THE USA: A GRASSROOTS REPORT FOR UNCED (n.d.) (providing reports from U.S. grassroots environmental organizations for intended audience of third-world grassroots NGOs); Sheela Patel et al., Squatting on the Global Highway: Community Exchanges for Urban Transformation, in GlOBAL CITIZEN ACTION 231 (Michael Edwards \& John Gaventa eds., 2001); Mary Tong, New Frontiers in Tijuana: U.S. $\mathfrak{F}$ Mexican Labor Forge a Common Future, BEYOND BORDERS, Spring 1994, at 16; and Baldemar Velasquez, Meeting the Transnational Corporate Challenge, BEYOND BORDERS, Winter 1992 , at 8 . 
asymmetrical power and privilege in the global economy. ${ }^{97}$

Horizontal conversations between workers of the global North and South will require northern participants to face some of the difficult $\mathrm{P}_{2}$-related tasks of learning about radical international inequality. However, these kinds of horizontal conversations will also afford those from both sides of the North-South divide an opportunity to share stories about their varied, but at least partly analogous, attempts to exert local and national sovereignty over powerful multinational corporations. Perhaps these conversations can constitute a ground for building transnational communities of interest that do not supplant membership in national polities, but overlap that membership and complicate it in critical and internationalist ways.

Of course, cross-national dialogues between and among disempowered constituencies will not achieve instant understanding. The contexts for work in different parts of the world are so different that even preparing for a simple exchange takes significant time and attention.

${ }^{97}$ Many social movement activists in debtor countries will have strong $P_{1}$ stories of their own to tell. The theme of sovereignty and democratic control of development strategies is a strong one in global conversations. Voices from Latin America that are critical of the proposed Free Trade Area of the Americas (FTAA) reveal repeated and abiding concern for the values and issues I group under $P_{1}$. For instance, in a statement issued at the Summit of the Peoples of America in Santiago, Chile, in April 1998 (a gathering of labor and community groups that served as a sort of "shadow conference" to the Presidential Summit on FTAA also taking place in Santiago at the time), the Forum argued that "[w]e must refuse to allow the global market, with the consent of our governments, to define the futures of our countries and our peoples. We must democratically build in our respective countries national sustainable development plans and from this starting point fight for our place in the world." Summit of the Peoples of America: Social and Economic Alternatives for the Americas (April 1998) (working draft, on file with author).

In a more recent compilation of statements from Latin Americans on the FTAA, the same thread continues to appear. For instance, the Peru Chapter of the Hemispheric Social Alliance noted:

Our governments are now subject to enormous pressures by the multilateral organizations, which are the principal actors in international trade today, resulting in a new kind of economic colonialism.... We defend the central role that the government should assume in order to ensure that the benefits of international trade and economic growth reach those who contribute to the creation of wealth.

Alliance fOr Responsible Trade, LATIN AMERICANS Against THE FTAA-ANOTHER AMERICAS IS POSSIBLE 7 (Karen Hansen-Kuhn ed., 2001). The Latin American Rural Platform on Integration included this plank: "Whatever changes may be in store for Latin American farming groups, it is imperative that they seek to regain autonomy.... Autonomy implies the ability of nations to democratically determine their own paths of development." Id. at 25. 
Much less will such dialogues in themselves create egalitarian relationships in the face of major and continuing material asymmetries. Social movement activists will be forced to recognize that, even in the midst of dialogue and interchange initiated to overcome these problems, questions of power and privilege, of community and exclusion, and of membership and boundedness will rear their stubborn heads. As citizens of the richest and most powerful nation on earth, Americans face a particularly tough assignment if we try to understand ourselves in a larger context, to recognize the asymmetry of our global position, and to imagine how our positions might affect the terms of our participation in global social movements. Our nation's history and power suggest potent reasons for adopting something like a strict scrutiny rule for all invocations of "We, the American people," whether in the context of $P_{1}$ exercises of jurisdiction or $P_{2}$ definitions of membership.

On the other hand, if U.S. social movements are especially exposed and obligated on this scene, we are not incommensurably different in having to examine critically our own position within a larger system of power relations. No person or movement anywhere is exempt from the need for critique. Every organization and movement must struggle with internal power dynamics and inequalities. All communities everywhere have at least some potential to exclude or subordinate those they put beyond or below the imaginary or physical boundaries they draw. ${ }^{98}$

\section{CONCLUSION}

When Benedict Anderson proffered his now well-known proposition that a nation is "an imagined political community," he sug-

${ }^{98}$ Even trying to think coherently about the multiplicities of identity and the ambiguities of power is a huge task, much less figuring out how to build social movements and frame issues in ways that recognize and accommodate those ideas. Of course, important social categories like sex, race, class, and nationality intersect, overlay, and combust. For an account that attempts to peel back multiple kinds of power and privilege, and then to devise situated strategies for dealing with them in the microsetting of a college classroom, see Michiko Hase, Student Resistance and Nationalism in the Classroom: Some Reflections on Globalizing the Curriculum, 13 FEMINIST TEACHER 90 (2001). An important contribution to thinking about the difficult hands-on work of building coalitions across difference is ERIC $\mathrm{K}$. YAMAMOTO, INTERRACIAL JUSTICE: CONFLICT AND ReCOnciliation IN POST-CIVIL RIGHTS AMERICA (1999). See also NANCY A. NAPLeS, COMMUNITY ACTIVISM AND FEMINIST POLITICS: ORGANIZING ACROSS RACE, Class, AND GENDER (1998) (offering "lessons from successful cross-race and cross-class coalition building, as well as cautions from failures to negotiate across differences"). 
gested that we look back beyond modern nationalism to older ways of thinking about state and society in order to gain perspective on our own contemporary assumptions." He identified religion, family, and dynasty, for instance, as systems that offered contrasting vantage points on nationalism. ${ }^{100}$ In making a specific contrast with dynasty, he observed that, unlike the modern national idea where "state sovereignty is fully, flatly, and evenly operative over each square centimetre of a legally demarcated territory," in the dynastic imagination the "state[] [was] defined by centres, borders were porous and indistinct, and sovereignties faded imperceptibly into one another."101

Today, twenty years after publication of Anderson's germinal book, new forms of sovereignty are coming into view; they are forms that may well look more like his dynastic description and less like the ideal modern nation-state. ${ }^{102}$ One recent theorist on citizenship sounds a related note when he asks whether the whole concept of citizenship is obsolete, "since its close association historically with closed political communities is inappropriate to the porous boundaries of a new global age." ${ }^{103}$ Another observer discerns a "shift from a territorially defined understanding of social life to a social imaginary built up more through flexible networks, relationships, and institutions than organized around geographically bounded spaces,"

\footnotetext{
99 BENEDICT ANDERSON, IMAGINED COMMUNITIES: REFLECTIONS ON THE ORIGIN AND SPREAD OF NATIONALISM 4-7 (rev. ed. 1991).

${ }^{100}$ See id. at 9-36 (discussing religion, family, and dynasty as the cultural roots of nationalism).

${ }^{101} I d$. at 19.

102 See SASKIA SASSEN, Losing CONTROL? SOVEREIGNTY IN AN AGE OF GLOBALIZATION (1996) (arguing that the growth of a global economy has fundamentally affected modern states by denationalizing territory formerly considered exclusive and by decentralizing sovereignty through shifting components of control to supernational entities); SASKIA SASSEN, THE GLOBAL GITY (1991) (proposing that the organization, focus, and integration of the world economy has transformed a few cities of vast, concentrated resources into global cities).

${ }^{108}$ KeITH FAULKS, CITIZENSHIP 132 (2000); see also Linda Bosniak, Citizenship Denationalized, 7 IND. J. GLOBAL LEGAL STUD. 447, 452 (2000) (arguing that citizenship is denationalized, and better understood by relation to its various components, such as legal status, conveyed rights, political activities, and common identity).

${ }^{104}$ Gay W. Seidman, Adjusting the Lens: What Do Globalizations, Transnationalism, and the Anti-Apartheid Movement Mean for Social Movement Theory?, in GLobAlIZATIONS AND SOCIAL MOVEMENTS, supra note 11, at 339, 340. Seidman seems to suggest here that social movements can themselves be imagined communities, that they might take on some aspects of sovereignty or confer citizenship as the state does. Meanwhile, Boa Santos recently made a provocative mirror-image point to Seidman's when he suggested that we may be entering a time and context when the state itself sometimes takes on the characteristics of a social movement. Boaventura de Sousa Santos, Re-
} 
the international social movement against apartheid as an example of such a "social imaginary." 0 "5 Others have undertaken fascinating inquiries into sovereignties of the past and of the margin, looking to lost models that seem strange to contemporary eyes, and turning to subordinate sources to help them envision new kinds of sovereignty and new kinds of citizenship. ${ }^{106}$

It may be that social movement frameworkers can draw on some of these "strange" images of sovereignty to suggest new kinds of communities and polities, and new sorts of membership and authority, ${ }^{107}$ suitable for such diverse tasks as globally linking local social movements, desegregating exclusive suburbs, governing multinational enterprises, planning for transnational watersheds, imagining the structure of an international living wage, or protecting the rights of migrant workers.

Of course, strange sovereignties are not necessarily better ones, as the above reference to dynasty should make clear. Sovereign communities could, for instance, be more "porous" and less "geographically bounded," more overlapping and "imperceptibly fading" while also being much less democratic, participatory, equitable, or sustainable than the forms of sovereignty we have now. In fact, it is precisely

marks at the Modern Law Review Colloquium (June 2001).

${ }^{105}$ Seidman, supra note 104 , at 348-53.

$1 \%$ Frameworkers who join the project of imagining new sovereignties (and new citizenships within them) may find that a turn to lost models or subordinate sources can help in the development of new designs. Santos, for instance, talks about the necessity for "unthinking" law, as part of a paradigmatic transition from modern to postmodern law. He suggests that this unthinking "will be initially guided by the suppressed or marginalized traditions of modernity, ... [and] will require some archeological excavation." BoAventura de SOUSA SANTOS, TOWARd A NEW COMMON SENSE: LAW, Science and Politics in the Paradigmatic Transition 96 (1995).

Indigenous law and other "plural" sources of thinking about sovereignty may likewise prove helpful. For one look at ways that globalization opens space for contemporary indigenous lawmaking, see Florence Passy, Supranational Political Opportunities as a Channel of Globalization of Political Conflicts: The Case of the Rights of Indigenous Peoples, in GLOBALIZING WORLD, supra note 17 , at 148 .

For a fascinating examination of the nature of urban citizenship in one premodern town prior to consolidation of the Dutch nation-state, see Maarten Prak, Burghers into Citizens: Urban and National Citizenship in the Netherlands During the Revolutionary Era (c. 1800), in EXTENDING CITIZENSHIP, RECONFIGURING STATES 17, 19-24 (Michael Hanagan \& Charles Tilly eds., 1999).

${ }^{107}$ In some ways, this is precisely what Gerald Frug is up to in his recent book. See Gerald E. Frug, City Making: BuIlding Communities Without Building, Walls 73-112 (1999) (discussing current realities of city life and conducting thought experiments by conceiving of cities as different kinds of "subjects" analogous to the human personality as understood by different contemporary ideologies). 
one of the points of this Article that formally democratic nation-states can be drained of many hard-fought attributes of democratic sovereignty without their popular electorates gaining any new forum, polis, or leverage to replace the old one. ${ }^{108}$ But it seems likely that going back to a singular, stable, bright-line sort of citizenship, associated strongly with a stable, bright-line sort of nationhood, is neither feasible nor desirable. So hopes for democracy will presumably have to find other ground.

This Article has described a dilemma I encountered in my own work as a volunteer rhetorician in a particular social movement that arose in the United States during the 1970s and 1980s in protest over the wave of plant-closings then sweeping the country. That movement no longer exists as a discrete phenomenon centered only on plant closings, but it has flowed into other currents that are still running. An array of campaigns focused on issues of economic justice and global economics has been generated from these contemporary currents, and they are grappling with tremendously important questions.

The dilemma this Article identifies is one that surfaced in the course of my efforts to help frame issues of economic justice under conditions of globalization. On the one hand, those of us involved in the plant-closing movement sought a frame that projected the importance of defending sovereignty and community in our national home. The "boundary imperative" these efforts highlighted seems especially sharp in these times when so many cultural, economic, and political communities are being flattened by the triumphal march of the ideology, law, and practice of free trade.

On the other hand, we were made painfully aware of the need for a frame that valued the opening and expanding of sovereignty and

\footnotetext{
${ }^{108}$ Perhaps this is a risk that jet-setting cosmopolitans, whether liberal or postmodern, should mark and consider if they care about democratic membership and participation. For an approach that takes the nation as a necessary foundation for citizenship, see DAVID MILLER, ON NATIONALITY (1995). For an effort to rethink the idea of national citizenship under the divided sovereignty emerging in Europe, see Jürgen Habermas, Citizenship and National Identity, in THE CONDITION OF CITIZENSHIP 20, 28-32 (Bart van Steenbergen ed., 1994). On the other hand, some thinkers suggest that, risky or not, the fading of the nation-state is underway and beyond our control, and that we should move on. See, e.g., Damian Tambini, Post-National Citizenship, 24 ETHNIC \& RACIAL STUD. 195, 195-98 (2001) ("National citizenship emerged, and national citizenship will pass.").
} 
community in our national home, and for a frame that asked Americans to recognize the powerful and not always benign place that our own nation holds in the world. This "openness imperative" also seems especially sharp in these times when so many people are on the move as a result of economic stress and strain. Today, mass migration and accelerated economic integration are starkly revealing the limited usefulness of geographical boundaries for delineating relevant communities of interest or desert. Moreover, America continues to be economically, politically, and militarily dominant in the international system, and actively involved in defining the new rule structure now under construction in international trade regimes.

A hope expressed or implied in this Article is that globally conscious social movements will come to thrive in the United States, movements focused on economic justice and capable of carrying on the best of what we began in the plant-closing campaigns of past decades, yet also capable of going significantly beyond the old ones in their awareness of the highly asymmetrical global system and their openness to the claims of the excluded and oppressed. Perhaps what I am finally suggesting here is that a central task of such social movements will be to spur, enable, and embody the project of imagining new kinds of communities that are simultaneously localist and internationalist. $^{109}$

I have also predicted above that if social movements in the United States attempt to take up this task, they will find themselves confronting some version of the dilemma revealed by the past efforts recounted here. People and communities throughout the global economy need polities that can exercise meaningful, deliberative sovereignty over local and global market relations. At the same time, Americans in particular need to understand that the more powerful the polity, the more urgent the need for reiterative skepticism about its role abroad, and the more likely it will be that global differenceincluding some new forms of global debt-must be recognized. ${ }^{10}$

${ }^{109}$ If the assignment seems arduous, perhaps it would be good to recall Margaret Keck and Kathryn Sikkink's reflection on the work of previous generations of social movement activists in organizing for abolition and for suffrage. They observed that "[o]ne of the main tasks that social movements undertake ... is to make possible the previously unimaginable by framing problems in such a way that their solution comes to appear inevitable." Margaret Keck \& Kathryn Sikkink, Historical Precursors to Modern Transnational Social Movements and Networks, in GLOBALIZATIONS AND SOCIAL MOVEMENTS, supra note 11 , at 35,35 .

${ }^{110}$ In adopting such a notion, Americans would be taking a stance opposite to that of NAFTA, which embraces a model of formal equality, claiming thereby to assure a 
I have no sure-fire solutions for these difficulties. The one concrete recommendation I offer here is that social movements in the North should cultivate stronger and wider channels of horizontal communication with their counterparts in the rest of the world-perhaps with occasional, respectful assistance from cosmopolitan intellectuals of the type assembled here for this Symposium."I My claim is that exchanges of stories and sharing of perspectives could provide all participants, but especially those in the North, with important instruction and support. Specifically, these exchanges might help social movement frameworkers survive and use the tension between the poles of home and globe, self and other, inside and outside that I explore but do not resolve in this Article. Such cross-border conversations might even equip us to start all over again, if and when the

"level playing field" for all the nations in the world. José Alvarez has brilliantly skewered NAFTA's investment chapter for its false symmetry:

The rhetoric of the NAFTA investment chapter is that of scrupulous neutrality and equal protection. Its text is grounded in symmetrical and reciprocal rights as between the NAFTA parties and their investors. This befits the treaty's claim that it is a "fair" contract between "sovereign equals." The reality is quite different. ... As few Mexican investors are likely to be in the position to penetrate the U.S. market, it is almost exclusively U.S., not Mexican, nationals that get the benefit of the investment chapter ... .

...

[T] he rhetoric of the NAFTA investment chapter suggests that all foreign investors, regardless of their bargaining power or the histories of particular companies, are all "innocents" abroad, equally needful of protection from allpowerful government interests bent on their destruction ....

....

The bottom line is that instead of the comprehensive, balanced, and truly reciprocal investment regime that it purports to be, the NAFTA investment chapter is merely a short-sighted, one-way rachet to reward and attract U.S. capital. Even those who assume that the attraction of foreign capital provides its own reward ought to be concerned should this treaty's imbalances undermine its promise to supply stable and enduring rights for foreign investors.

[T] he investment chapter is not as color-, class-, and ethnicity-blind as its rhetoric suggests....

José E. Alvarez, Critical Theory and the North American Free Trade Agreement's Chapter Eleven, Speech Presented at Hispanic National Bar Association (Oct. 4, 1996), in 28 U. MIAMI INTER-AM. L. REV. 303, 304, 307, 310 (1996-97) (footnote omitted).

"II Elsewhere I urge that scholars interested in problems of poverty should more often become engaged with poor people and their movements, whether through convening participatory research projects, or simply writing (and otherwise creating) more often for popular audiences. Although I did not couch my suggestions in that other essay in terms of social movement theory, it would be possible to see it in retrospect as a call for more academics to involve themselves in framingwork. Fran Ansley, Who Counts?: The Case for Participatory Research, in LABORING BELOW THE LINE: THE NEW ETHNOGRAPHY OF POVERTY, LOW-WAGE WORK, AND SURVIVAL IN THE NEW ECONOMY (Frank Munger ed., forthcoming 2002). 
world's egalitarian social movements succeed in reviving or building sovereignties where people participate more actively and equitably in setting the parameters for development. Then, as now, we will undoubtedly need the capacity to mount both spirited defense and vigilant critique-even of the new, more equitable, democratic, and sustainable local/global communities we are hoping to dream and build. 
* $* * * * *$ 